\title{
New results concerning the pedo- and chronostratigraphy of the loess-palaeosol sequence Attenfeld (Bavaria, Germany) derived from a multi-methodological approach
}

\author{
LYDIA KRAUSS, ${ }^{1,2} *$ (1) NICOLE KLASEN, ${ }^{3}$ PHILIPP SCHULTE ${ }^{1}$ (1) and FRANK LEHMKUHL ${ }^{1}$ (]) \\ ${ }^{1}$ Department of Geography, RWTH Aachen University, Germany \\ ${ }^{2}$ Geomorphology and Soil Science, Technical University of Munich, Germany \\ ${ }^{3}$ Institute of Geography, University of Cologne, Germany \\ Received 8 October 2020; Revised 21 February 2021; Accepted 22 February 2021
}

\begin{abstract}
Loess-palaeosol sequences (LPS) represent important records of palaeoenvironmental dynamics throughout the Quaternary. During the Pleistocene's dry and cold phases, the Danube's riverbed was one of the major sources for loess sediments that built up LPS in southern Germany and southeastern Europe. Surprisingly, studies addressing Bavarian LPS along the Danube River often lack actuality. The Attenfeld site was one of them and is often cited as a typical LPS. Nevertheless, the site's previous interpretations are based on a few empirical data and field observations. Considering the site's closeness to the sediment's source area, the Alps, and the region's importance in Middle and Upper Palaeolithic migrational movements, those former renditions needed an evaluation. Therefore, we applied a multi-proxy approach (including analyses of grain-size distribution, element composition, and sediment colour attributes) combined with optically stimulated luminescence. Based on our findings, we conclude that the Attenfeld site's former interpretations might be too generalised. We identified units that were not mentioned by previous studies (e.g. Early Glacial dark greyish horizon). Field observations, sediment characteristics, and age estimates indicate sediment deposition of the dated units partly before MIS 4, which contrasts with previous interpretations. The results further demonstrate how sensitive LPS are to environmental settings and dynamics. Copyright (C) 2021 The Authors. Journal of Quaternary Science Published by John Wiley \& Sons Ltd.
\end{abstract}

KEYWORDS: geochemistry; loess sediments; OSL; palaeopedology; Quaternary; sedimentology

\section{Introduction}

Especially in the Northern Hemisphere, loess-palaeosol sequences (LPS) represent substantial records of terrestrial palaeoenvironmental developments throughout the Quaternary (Zeeden et al., 2016; Schaetzl et al., 2018; Fischer et al., 2021). Loess covers around $10 \%$ of the Earth's landmasses as an aeolian, predominately silt-sized, and calcareous loose sediment. Interbedded soils result from repeated changes in climatic and environmental conditions during the Pleistocene (Pécsi, 1990; Wright, 2001; Muhs, 2007; Kels and Schirmer, 2011; Pye, 1995, 2015).

In southern Germany, the Alps are the primary sediment source for LPS. High physical weathering rates of bedrock resulted in subsequent transportation and deposition of suspended load by the Danube's tributaries in the Alpine foreland and further east. This provided silty material for aeolian erosion and loess accumulation in the Danube River's vicinity when the braided river system was largely dried out during the Pleistocene's cold and dry phases in Europe. Yet, the oceanic influence in western Europe generally causes more humid soil-moisture regimes in southern Germany than in continental and drier regions like southeastern Europe (Antoine et al., 2009a; Marković et al., 2015; Lehmkuhl et al., 2020). In combination with slope angles above $2^{\circ}$, this can intensify geomorphologic processes in LPS, like slope wash up to a complete erosion of several units (Rousseau

${ }^{*}$ Correspondence: L. Krauß, Department of Geography, as above.

E-mail: lydia.krauss@geo.rwth-aachen.de et al., 2013; Lehmkuhl et al., 2016). Transregional characteristics of LPS can therefore be hugely influenced by local settings and regional parameters, which has to be taken into account when analysing LPS in southern Germany.

While LPS have been intensively studied in other regions of Germany over recent decades, e.g. along the Rhine River (Schirmer, 2000; Antoine et al., 2001; Bibus et al., 2007; Kels, 2007; Frechen and Schirmer, 2011; Klasen et al., 2015), studies targeting LPS along the Danube River often lack actuality and date back several decades in Bavaria (Brunnacker, 1953; Jerz, 1993). Apart from a few exceptions (Bibus, 1995; Becker-Haumann and Frechen, 1997; Mayr et al., 2017), those studies often miss a high-resolution multiproxy approach and the application of direct dating methods. The absence of recent detailed research on Bavarian LPS along the Danube River causes a spatial gap of state-of-the-art information concerning environmental dynamics between the Carpathian Basin and western Europe. This is especially important in the archaeological context of anatomically modern humans' (AMH) dispersal and Neanderthals' extinction during the last glacial as LPS can provide additional information on the palaeoenvironmental setting. The Danube River is viewed as a corridor that AMH dispersal followed. Specifically in Germany, archaeological findings connected to the Aurignacian ( 30-43 ka according to Hauck et al., 2018) concentrate around the Danube River and its tributaries like the Altmühl River (Uthmeier, 2003; Floss et al., 2016).

As one of the few still existing southern Bavarian LPS in the Danube River's vicinity, the Attenfeld site is often referred to as 
a typical Bavarian LPS. Bleich (1989) and Jerz et al. (1993) described the section based on pedological and sedimentological properties (soil description and horizon-wise sampling). Following their pedostratigraphy, the site includes the last interglacial-glacial cycle. Even though the pedostratigraphic concept's importance is indisputable, state-of-the-art detailed sediment analyses and chronological classification by a direct dating approach are crucial for a robust interpretation of palaeoenvironmental dynamics. To establish a first detailed data-based picture of environmental variations in Attenfeld, we generated new high-resolution data $(5 \mathrm{~cm}$ sampling resolution) using a multi-proxy approach (analyses of grainsize distribution, element composition, and sediment colour attributes). Additionally, we obtained two age estimates based on optically stimulated luminescence (OSL) ${ }^{1}$.

\section{Regional setting and proposed local stratigraphy}

The LPS Attenfeld (48 46'39.828" N; $11^{\circ} 11^{\prime} 43.188^{\prime \prime} \mathrm{E} ; 424 \mathrm{~m}$ asl; Fig. 1) was situated in a former quarry (Tertiary sands) that is now used as a landfill site ${ }^{2}$. It is located around $4 \mathrm{~km}$ north of the Danube River and about $25 \mathrm{~km}$ west of Ingolstadt within the Franconian Jura's southern extent.

During the Pleistocene, the Franconian Jura was part of the periglacial zone between the Fennoscandinavian ice sheet in the north and the Alpine valley glaciation in the south. Here, the most abundant aeolian sediment is loess. The thickness of LPS ranges from less than 1 to above $15 \mathrm{~m}$. Loess sediments from the last glacial are more widespread and better preserved than loess from previous glaciations. Some last glacial LPS can reach up to $5 \mathrm{~m}$ in thickness and show soils and soil complexes, tundra gleys, and loess layers containing up to $45 \% \mathrm{CaCO}_{3}$ (Jerz et al., 1993). Older loess sediments are commonly more chemically weathered, decalcified, and not as abundantly distributed (Strattner and Rolf, 1995).

Bleich (1989) first described the LPS Attenfeld. According to Jerz et al. (1993) and Jerz and Grottenthaler (1995), the $~ 8.5 \mathrm{~m}$ thick LPS overlies Tertiary sands. They relate the aeolian sediments to the Middle and Upper Pleistocene, followed by Holocene soil development, and assume that at least three interglacial-glacial cycles are preserved here. Bleich (1989) discovered presumably Lower Palaeolithic (2.7 ma to $200 \mathrm{ka}$ ) artefacts in a fluvial gravel layer below the oldest soil complex. Accordingly, he attributed the lower part of the LPS to the timeframe of 450-500 ka (pedological analysis by Jerz, 1993). However, morphological analyses of the artefacts point towards Middle Palaeolithic origin and, consequently, raise doubts about this timeframe (Haidle and Pawlik, 2010).

We have focused on the upper three metres in the present paper since they presumably cover the last interglacial-glacial cycle and the Holocene. According to previous observations (Brunnacker, 1953; Jerz, 1993), the site's Upper Pleistocene was characterised by (bottom to top) a strongly developed, partly waterlogged Eemian Bt horizon (MIS 5e), followed by the 'lower loess' layer (MIS 4), a brunified sediment layer (MIS 3), and the 'upper loess' layer (MIS 2) with a $1 \mathrm{~m}$ thick Holocene Luvisol at the top.

\footnotetext{
${ }^{1}$ Due to the nature of the OSL sampling protocol, it was not possible to collect more samples without lowering the reliability of the age estimates tremendously. The units not sampled were either too thin for sampling or appeared to be altered by geomorphological processes. Since a profile wall is just a 2D-image, but OSL tubes take 3D-samples, it wasn't guaranteed that the thin units wouldn't have a slope angle resulting in overlapping of the units in the tube sample.

${ }^{2}$ The site has not been accessible since 2018.
}

\section{Methods}

We took samples continuously in a $5 \mathrm{~cm}$ resolution to analyse grain-size distribution, element composition, and sediment colour attributes. We further collected two OSL samples from homogeneous layers. The other units' small thickness or reworked character prevented additional sampling for OSL since we wanted to avoid sampling partially bleached sediments (Nelson et al., 2015). We divided the profile into four main units and up to four sub-units based on sediment properties like colour differences, pedofeatures (reduction, oxidation, concretions, clay coatings, etc.), grain-size variations (sand/silt/clay), and signs of material reworking by bioturbation, cryoturbation and solifluction (Fig. 2).

\section{Grain-size analyses}

To analyse the grain-size distribution of the sediment samples (dried at $35^{\circ} \mathrm{C}$, homogenised, and sieved at $2000 \mu \mathrm{m}$ ), a laser diffraction particle size analyser (LS13320, Beckman Coulter) was used, and the Lorenz-Mie theory was applied (Fluid RI: 1.33; Sample RI: 1.55; Imaginary RI: 0.1; ISO 13320-1, 1999; Özer et al., 2010; Schulte et al., 2016). The definition of grainsize classes followed the ISO standard 14688-1 (2002; Allen and Thornley, 2016; Blott and Pye, 2012; ISO 11277, 2002; Pye and Blott, 2004).

The grain-size index (GSI), as an index for wind dynamics and atmospheric dust, was calculated by GSI $=\frac{26 \text { to52.6 } \mathrm{cm}}{<26 \mu \mathrm{m}}$ (Rousseau et al., 2002, 2007; Antoine et al., 2009b). To identify shifts from low to high wind dynamics, the U-ratio

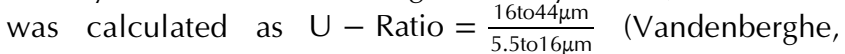
1985; Vandenberghe et al., 1997; Vandenberghe and Nugteren, 2001).

The $\triangle G S D$ (difference of grain-size distribution) was calculated as an indicator of pedogenic alteration intensity after Schulte and Lehmkuhl (2018). Two different optical models, the Fraunhofer approximation and the Lorenz-Mie theory (de Boer et al., 1987), are commonly used, to calculate the grain-size distribution from diffraction patterns. The most important advantage of the Mie theory over the Fraunhofer approximation is that it considers the complex refractive indices of particles and the suspension fluid (ISO 13320, 2020). The complex refractive index depends on the mineral properties of the particle mixture. Therefore, the difference of the GSDs $(\triangle G S D)$ calculated from the two models is sensitive to the mineral composition of a sample (Schulte and Lehmkuhl, 2018). Generally, post-depositional increases of the submicron grainsize fraction are either connected to cryogenic-induced physical breakdown or are a result of secondary clay mineral production caused by chemical weathering (Schaetzl and Thompson, 2015; Amelung et al., 2018). As pedogenically formed clay minerals have strongly irregular shapes (e.g. needles or plates; Buurman et al., 2001; Amelung et al., 2018), they end up in a more complex laser scattering pattern that is better considered by the Lorenz-Mie theory. As a result, lower $\triangle \mathrm{GSD}$ values speak for enhancements of secondary clay minerals. Thus, $\triangle \mathrm{GSD}$ is a robust indicator of post-depositional chemical weathering in LPS that is virtually not affected by cryogenic processes (Schulte and Lehmkuhl, 2018).

\section{Geochemical analyses}

To determine element concentrations, an $8 \mathrm{~g}$ aliquot of each sample (dried at $35^{\circ} \mathrm{C}$, homogenised, sieved at $63 \mu \mathrm{m}$, and dried for additional $12 \mathrm{~h}$ at $105^{\circ} \mathrm{C}$ ) and $2 \mathrm{~g}$ of wax binder (Fluxana Cereox) were mixed, homogenised, and pressed into a pellet at 19.2 MPa for $120 \mathrm{~s}$. Sample analyses were 


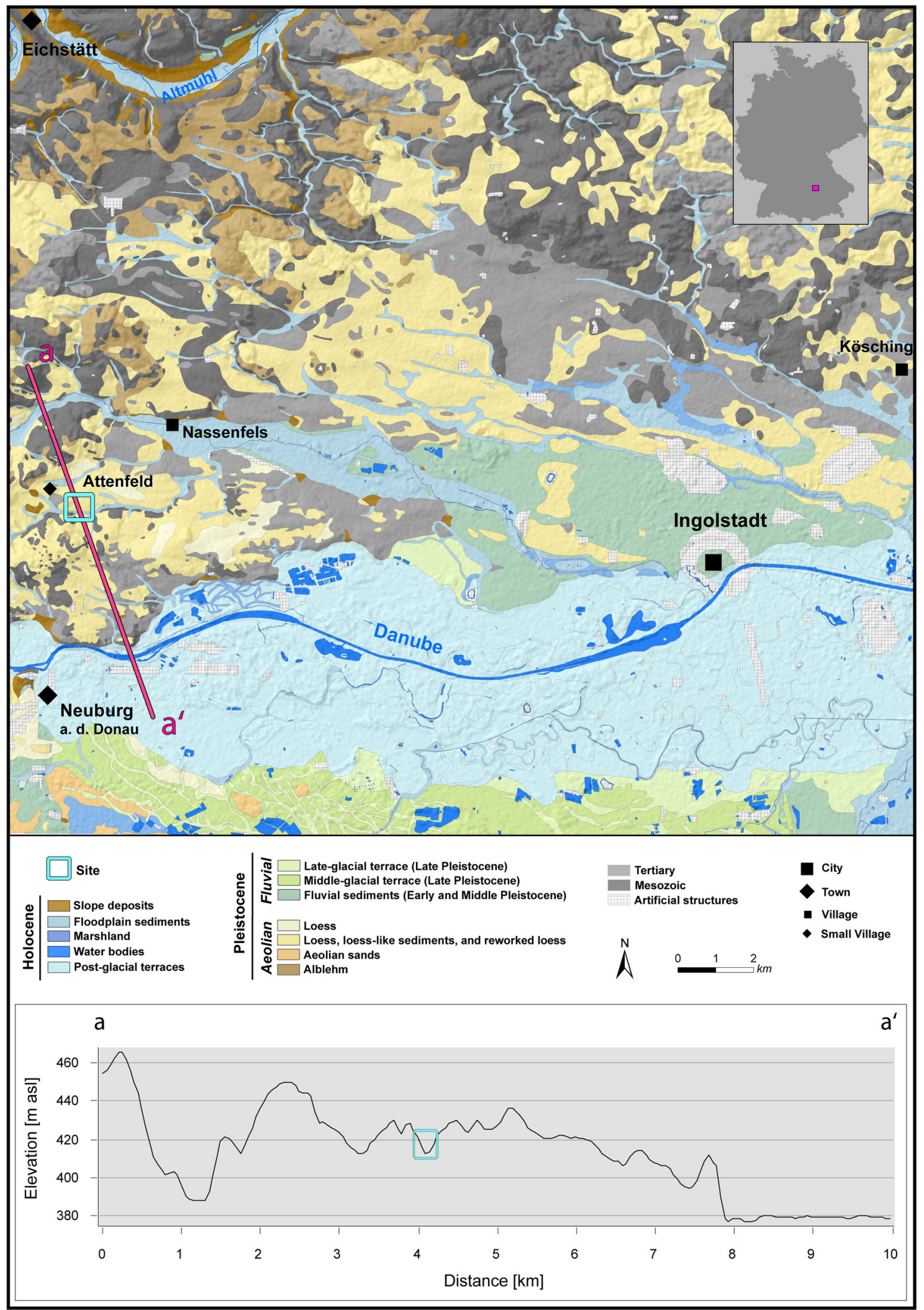

Figure 1. Geological map of the research area; below the map, an elevation profile following the red transect on the map; cyan rectangle marks the Attenfeld site (modified after Bayerisches Landesamt für Umwelt, 2020). [Color figure can be viewed at wileyonlinelibrary.com]

conducted with an energy dispersive X-ray fluorescence (ED-XRF) spectrometer (SPECTRO XEPOS, SPECTRO Analytical Instruments $\mathrm{GmbH}$ ). The element concentrations were used for, e.g., weathering proxies $\mathrm{Rb} / \mathrm{Sr}, \mathrm{Ba} / \mathrm{Sr}$ (Krauß et al., 2016, 2018). The oxide concentrations were calculated by using element-specific conversion constants. The chemical index of alteration (CIA) was calculated after Nesbitt and Young (1982):
$\mathrm{ClA}=\frac{\mathrm{Al} 2 \mathrm{O} 3}{\mathrm{Al} 2 \mathrm{O} 3+\mathrm{Na} 2 \mathrm{O}+\mathrm{CaO}_{*}+\mathrm{K} 2 \mathrm{O}} * 100$ (in molar proportions; $\mathrm{CaO} *$ refers to siliceous $\mathrm{Ca}$, calculated as mass $\%$ of $\mathrm{Na}_{2} \mathrm{O} /$ molar mass of $\left.\mathrm{CaO}\left(56.0774 \mathrm{gmol}^{-1}\right)\right)$. The chemical proxy of alteration (CPA) was calculated by $\mathrm{CPA}=\frac{\mathrm{Al} 2 \mathrm{O} 3}{\mathrm{Al} 2 \mathrm{O} 3+\mathrm{Na} 2 \mathrm{O}} * 100$ (in molar proportions; McLennan, 1993; Cullers, 2000; Buggle et al., 2011; Schatz et al., 2015). The total carbon (TC) contents were 

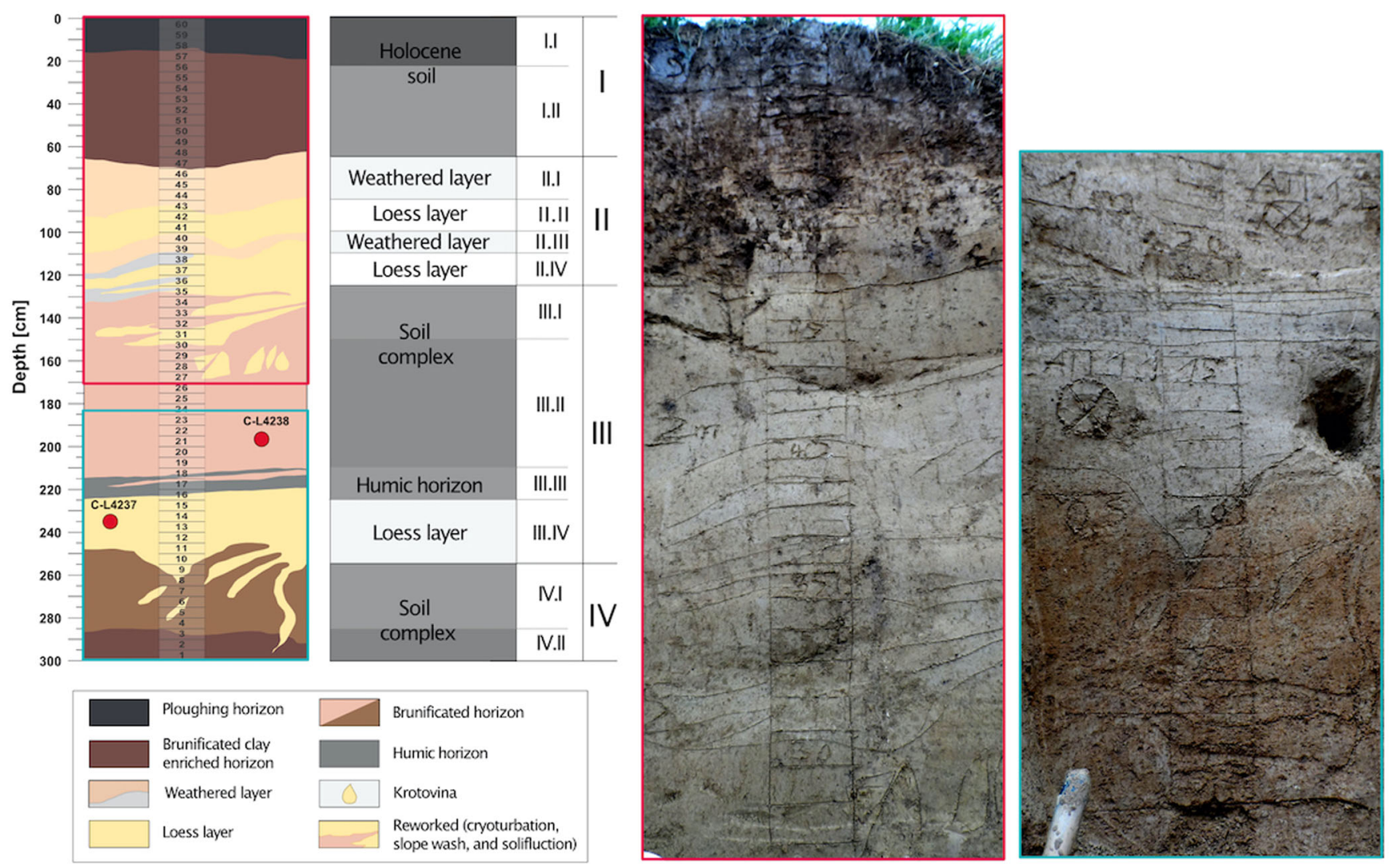

Figure 2. Profile drawing of the Attenfeld section with sample depths (red dots $=$ OSL samples; continuous sample line = sedimentological samples) and unit division following field observations on the left and photos (red frame $=$ upper part; blue frame $=$ lower part) on the right. The colours of the profile drawing are intentionally accented for better visibility of individual layers and layer boundaries. [Color figure can be viewed at wileyonlinelibrary.com]

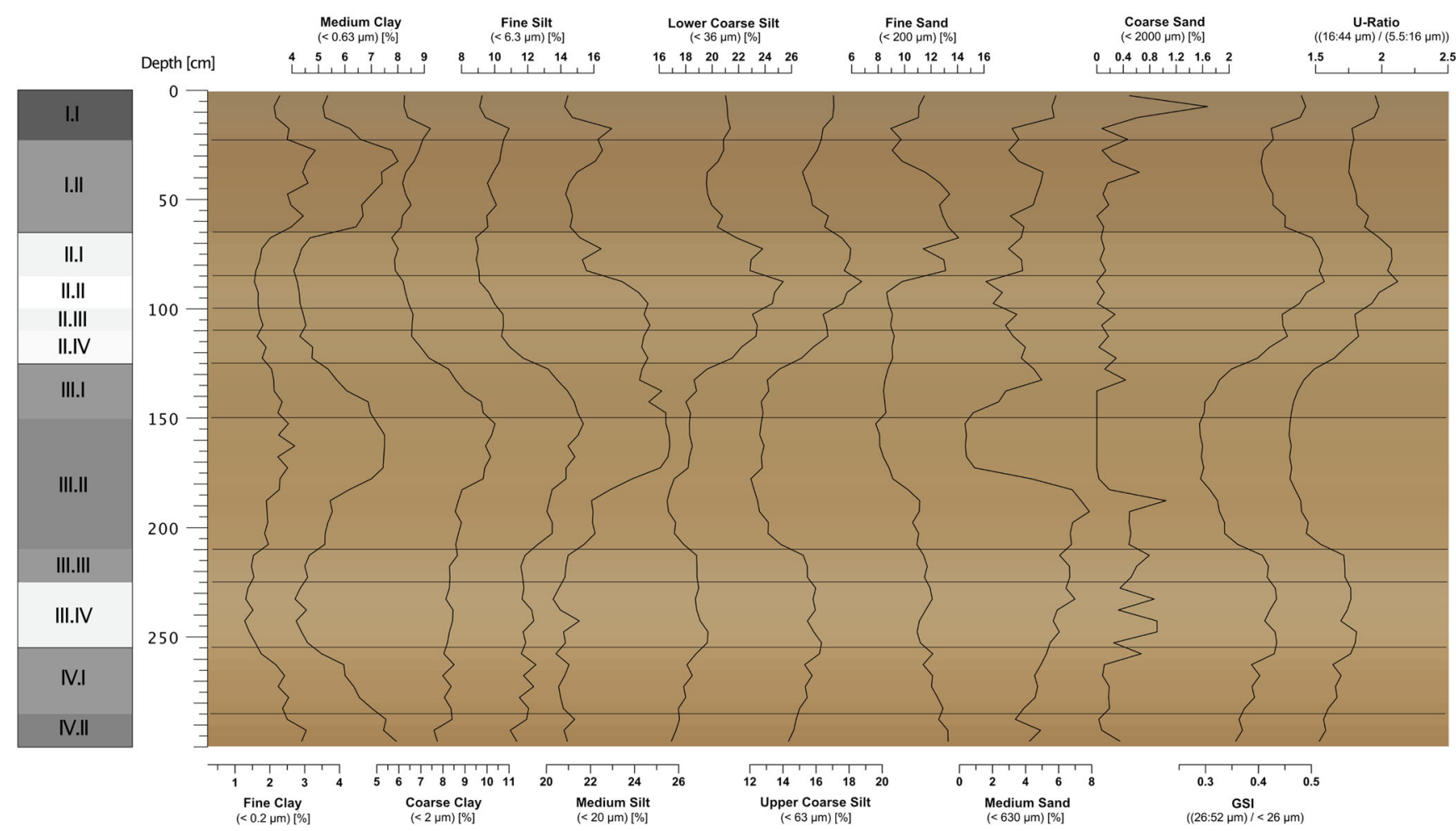

Figure 3. Detailed grain-size classes (fine clay: $0.04-0.2 \mu \mathrm{m}$, medium clay: $0.2-0.63 \mu \mathrm{m}$, coarse clay: $0.63-2 \mu \mathrm{m}$, fine silt: $2-6.3 \mu \mathrm{m}$, medium silt:

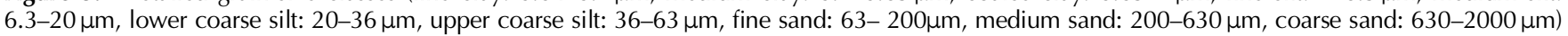
(after ISO 14688-1, 2002; see also Blott and Pye, 2012), GSI and 269 U-ratio plotted against depth [cm] (with colour data plotted in the background). [Color figure can be viewed at wileyonlinelibrary.com] 
quantified by thermal conductivity using a CHNS-Analyzer (HECAtech EuroEA3000). The carbonate content as an equivalent to calcium carbonate was volumetrically measured using a calcimeter on bulk samples (air-dried, homogenised, and sieved at $2000 \mu \mathrm{m}$ ) and is expressed as $\mathrm{CaCO}_{3}$ here (ISO 10693, 1995; Schaller, 2000). Organic carbon $\left(\mathrm{C}_{\mathrm{org}}\right)$ was then calculated by $\mathrm{C}_{\text {org }}=\mathrm{TC}-\left(\mathrm{CaCO}_{3}^{*} 0.12\right)$.

\section{Colour measurements}

The sediment colours were determined using a spectrophotometer (Konica Minolta CM-5) on dry, homogenised, and sieved $(<2000 \mu \mathrm{m})$ samples. The CIELAB values display colour as chromaticity coordinates on red-green $\left(\mathrm{a}^{*}\right)$ and blue-yellow $\left(b^{*}\right)$ scales. The $L^{*}$ values indicate the extinction of light $(0=$ absolute black to $100=$ complete white; Eckmeier et al., 2010; Gocke et al., 2014; Sprafke, 2016; Vlaminck et al., 2016; Zeeden et al., 2017). Colour data was plotted after Zeeden et al. (2017) and used as a background in two proxy data graphs (Figs 3 and 5). A correlation matrix is used to visualise the correlation strengths between $\mathrm{C}_{\text {org }}, \mathrm{CaCO}_{3}$, major grain-size classes, CIELAB values, and iron oxides within the complete section and $\mathrm{CaCO}_{3}$-containing units (Fig. 6).

\section{Luminescence dating}

Two samples were collected from the profile at $2.4 \mathrm{~m}$ (C-L4237) and $2.0 \mathrm{~m}$ (C-L4238) depths (Table 1). Laboratory treatment included $\mathrm{HCl}(30 \%), \mathrm{H}_{2} \mathrm{O}_{2}(10 \%)$, and sodium oxalate to remove carbonates, organic material and clay. Coarse grain potassium feldspars $(90-125 \mu \mathrm{m})$ were extracted with heavy liquid density separation $\left(\rho_{1}=2.58 \mathrm{gcm}^{-3}\right)$. All measurements were carried out on an automated Risø TL/OSL DA 20 reader equipped with a calibrated ${ }^{90} \mathrm{Sr}$ beta source. The samples were measured using the post-infrared infrared-stimulated luminescence signal measured at $290{ }^{\circ} \mathrm{C}$ (pIRIR 290 ; Thiel et al., 2011). Stimulation was carried out with infrared diodes $(870 \mathrm{~nm}$, full width at half maximum $=40 \mathrm{~nm})$, and the signals $(1 \mathrm{~mm}$ aliquots) were detected through an interference filter $(410 \mathrm{~nm})$. The most appropriate prior IR stimulation temperature was obtained in a laboratory experiment (Buylaert et al., 2012) using a range of different temperatures from 50 to $180^{\circ} \mathrm{C}$. The initial $4 \mathrm{~s}$ of the signal minus a background of the last $20 \mathrm{~s}$ was used for feldspar dating. To further test the pIRIR 290 protocol's performance, a dose recovery test was carried out using $\mathrm{plR}_{110} \mathrm{pIR}_{290}$ stimulation. In this test, the samples were illuminated for $24 \mathrm{~h}$ in a Hönle Sol2 solar simulator followed by laboratory beta irradiation in the range of the natural dose. The laboratory dose was subsequently recovered using SAR measurements. We preferred post-infrared infrared stimulation because this luminescence signal is expected not to fade (Thomsen et al., 2008; Buylaert et al., 2012). To assess equivalent dose overestimation due to the slower resetting of the pIRIR ${ }_{290}$ signal, the $\mathbb{I R}_{50}$ signal was measured (Wallinga et al., 2000; Preusser et al., 2005) too. Fading of the $\mathrm{IR}_{50}$ signal was recorded following the protocol of Auclair et al. (2003), and the approach of Huntley and Lamothe (2001) was used to correct the $\mathbb{I}_{50}$ age estimates. Data analyses were performed using the Risø Luminescence Analyst software (version 4.31.9). Equivalent doses were calculated with an arithmetic mean. The environmental dose rate was measured using high-resolution gamma-ray spectrometry. The dose rate was calculated using the conversion factors of Guérin et al. (2011). The internal beta dose-rate contribution of the feldspar samples was calculated by assuming a potassium content of $12.5 \pm 0.5 \%$ (Huntley and Baril, 1997). An a-value of $0.12 \pm 0.05\left(p / R_{110} I R_{290}\right)$ and $0.07 \pm 0.02\left(I_{50}\right)$ was used to account for the different efficiency alpha radiation contributions to the luminescence signal compared to beta and gamma

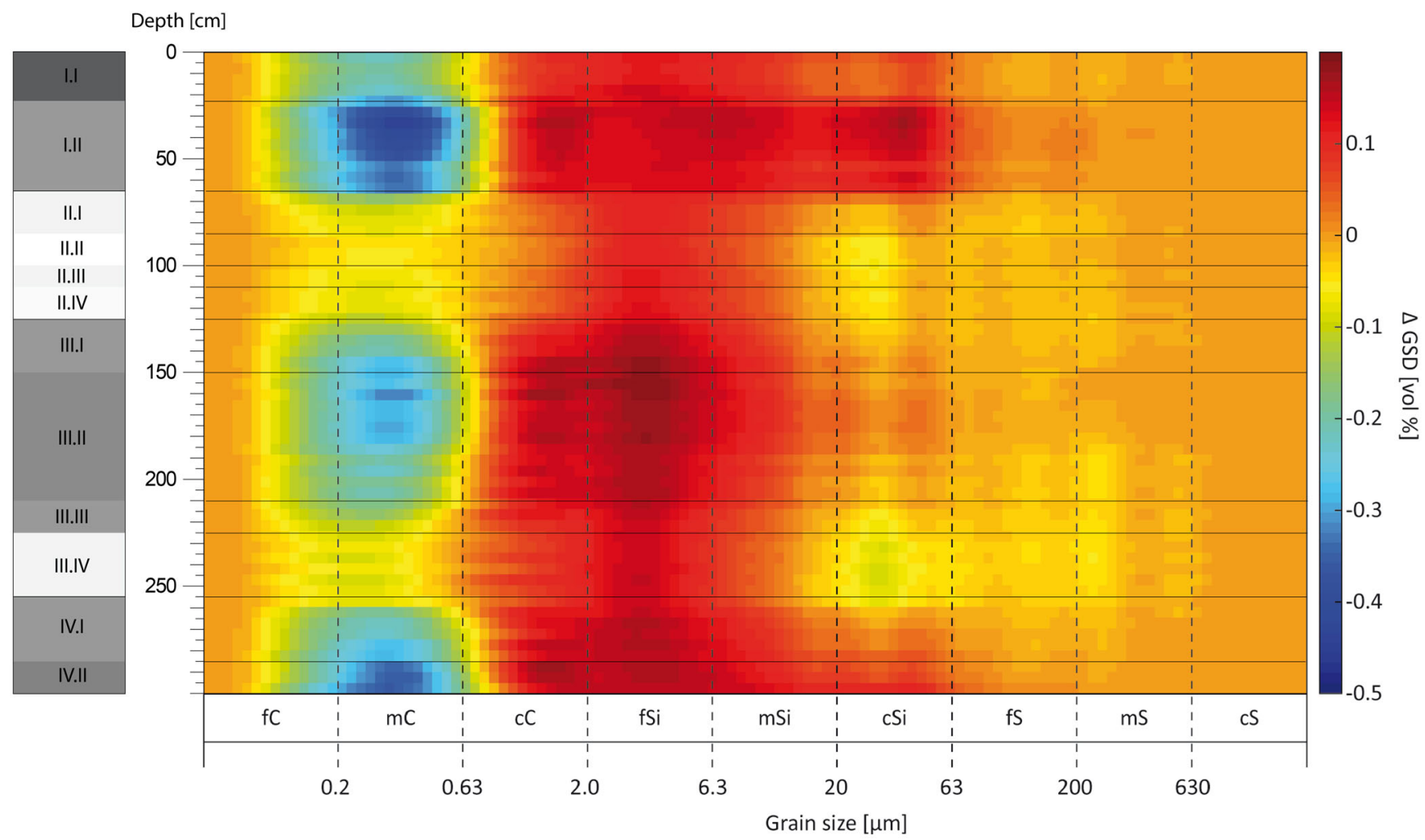

Figure 4. Heatmap showing the $\triangle \mathrm{GSD}$ (grain-size frequency calculated with the Fraunhofer approximation (FH) - GS frequency calculated with the Lorenz-Mie theory (Mie)) of all samples plotted against depth $[\mathrm{cm}]$. The $\triangle$ GSD is shown for each of the 116 grain-size classes resulting from the laser diffraction analysis (Schulte and Lehmkuhl, 2018). The dotted lines separate the classic grain-size fractions (clay (C): $0.04-2 \mu \mathrm{m}$, fine silt (fSi):

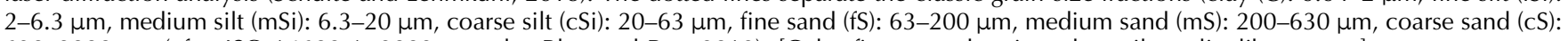
630-2000 $\mu \mathrm{m}$ (after ISO 14688-1, 2002; see also Blott and Pye, 2012). [Color figure can be viewed at wileyonlinelibrary.com] 


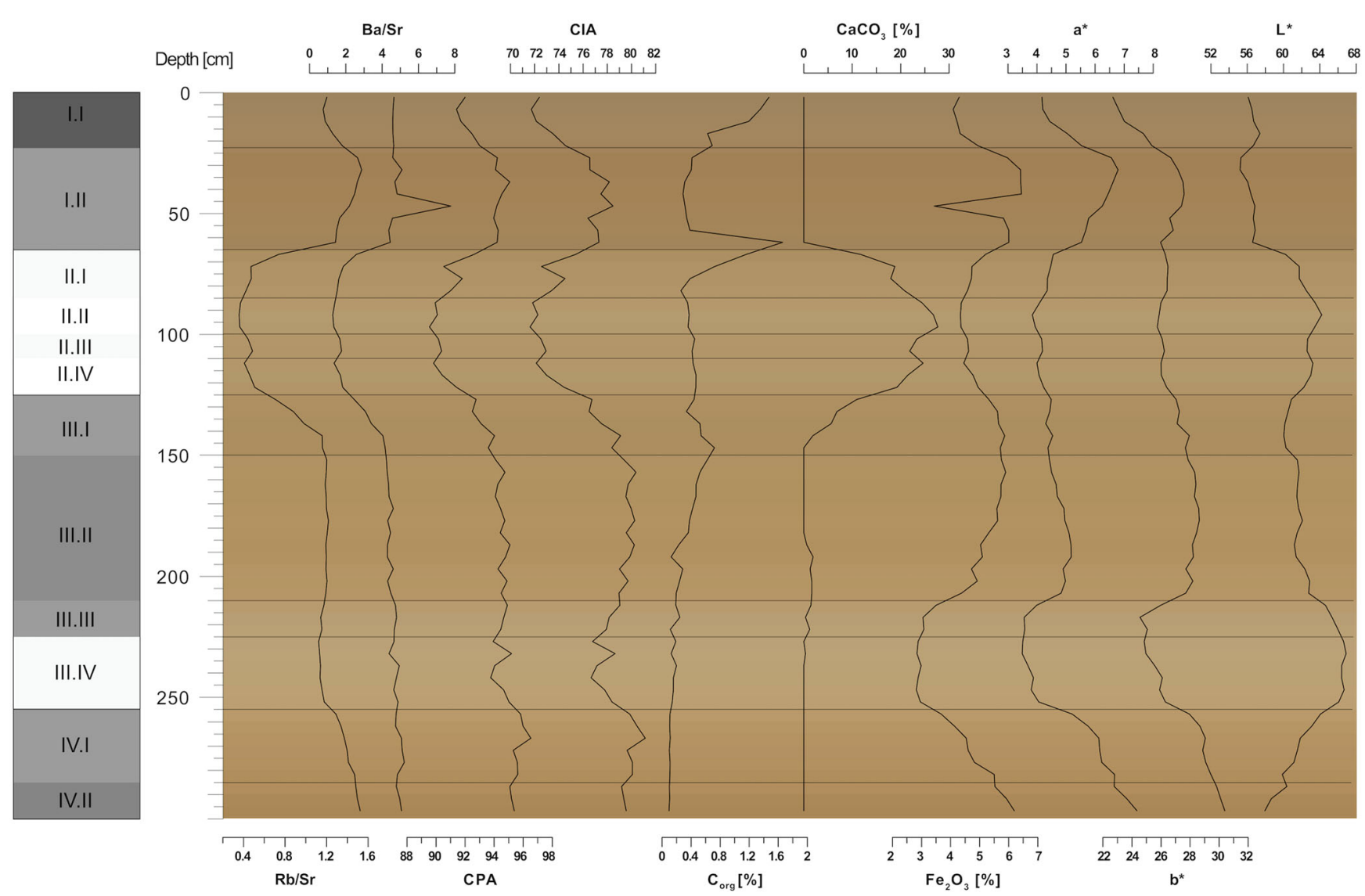

Figure 5. Weathering indices and colour data in relation to the simplified lithology based on defined units, plotted against depth [cm] (with colour data plotted in the background). [Color figure can be viewed at wileyonlinelibrary.com]

radiation. Beta attenuation factors of Brennan (2003) and Mejdahl (1979) were used. The cosmic dose rate was calculated following Prescott and Hutton (1994).

\section{Results}

\section{Stratigraphy}

Generally, the section's composition (Fig. 2) includes several sediment layers. Some show signs of weathering, soil formation, and reworking (bioturbation, cryoturbation, solifluction). The lowest layer is a $+15 \mathrm{~cm}$-thick and dark brown soil horizon (unit IV.II) followed by an $\sim 35 \mathrm{~cm}$-thick and lighter brownish horizon (unit IV.I) upwards. This horizon shows partial mixing with the $\sim 45 \mathrm{~cm}$-thick and yellowish loess layer above (unit III.IV). Unit III.III, an $\sim 10 \mathrm{~cm}$-thick dark greyish horizon, overlies the loess. The subsequent unit is an $\sim 60 \mathrm{~cm}-$ thick horizon composed of brunified material (unit III.II). At the bottom, it shows signs of sub-horizontal layering with the greyish horizon below. Above, the $20 \mathrm{~cm}$-thick horizon (unit III.I) shows signs of cryoturbation and mixing with the overlying yellowish loess layer. The $\sim 65 \mathrm{~cm}$-thick loess package shows a wavy layering of four different, partly chemically weathered layers (unit II). The top of the profile is characterised by an $\sim 65 \mathrm{~cm}$-thick Holocene soil with a welldeveloped Bt and Ap horizon (unit I.II and unit I.I).

\section{Grain-size distribution}

The results of the grain-size analyses are presented as grainsize classes, GSI, and U-ratio (Fig. 3) and as a heatmap of the $\triangle$ GSD plotted with depth (Fig. 4). The sequence's base is characterised by a high content of medium and fine clay- sized particles (an overall clay content of $\sim 18 \%$ ) and a sand content of $\sim 18 \%$. Within unit $I V$, the clay content reduces towards the overlying unit III.IV, whereas the coarse silt fraction increases. In unit III.IV, clay values are low while coarse silt, medium sand, and coarse sand are enhanced. In unit III.II, the fraction below $20 \mu \mathrm{m}$ increases slowly to the disadvantage of coarse silt and fine sand. Within the upper part of unit III.II, the medium and coarse sand fractions are absent to the advantage of the fraction below $63 \mu \mathrm{m}$. In unit III.I, the fraction below $20 \mu \mathrm{m}$ decreases while the coarser fraction $(>20 \mu \mathrm{m})$ increases again. The coarse silt-sized fraction shows maximum values in unit $I I$, while the fraction $<20 \mu \mathrm{m}$ strongly reduces. The sub-units show small variations between each other. Coarse silt values are highest in unit II.II, and the fine sand fraction is strongly enhanced in unit II.I compared to the other sub-units of unit II. Unit I.II shows a strongly enhanced clay content, while medium and coarse silt have reduced values. In unit I.I, the clay content drops again to the advantage of the fraction $>20 \mu \mathrm{m}$.

The GSI and U-ratio show maximum values in units III.IV and II. The lowest values are shown in units III.II and III.I. In unit I.I, a slight increase in the GSI and U-ratio is visible.

The $\triangle$ GSD (Fig. 4) shows low values within the medium clay fraction in units IV, III.II, and I. In unit I.II, $\triangle$ GSD values drop to -0.5 vol\%, while in units III. II and IV minimum values are between -0.4 and -0.3 vol\%.

\section{Weathering indices}

At the bottom of the sequence, the weathering indices $\mathrm{Rb} / \mathrm{Sr}$, $\mathrm{Ba} / \mathrm{Sr}, \mathrm{CIA}$, and $\mathrm{CPA}, \mathrm{Fe}_{2} \mathrm{O}_{3}, \mathrm{a}^{*}$, and $\mathrm{b}^{*}$ show high values, while $\mathrm{L}^{*}$ and $\mathrm{C}_{\text {org }}$ are low, and $\mathrm{CaCO}_{3}$ is absent (Fig. 5). Towards unit III, $\mathrm{Rb} / \mathrm{Sr}, \mathrm{Fe}_{2} \mathrm{O}_{3}$, $\mathrm{a}^{*}$ and $\mathrm{b}^{*}$ more or less decrease and $L^{*}$ increases. In unit III.IV, $\mathrm{Fe}_{2} \mathrm{O}_{3}$, $\mathrm{a}^{*}$ and $\mathrm{b}^{*}$ 

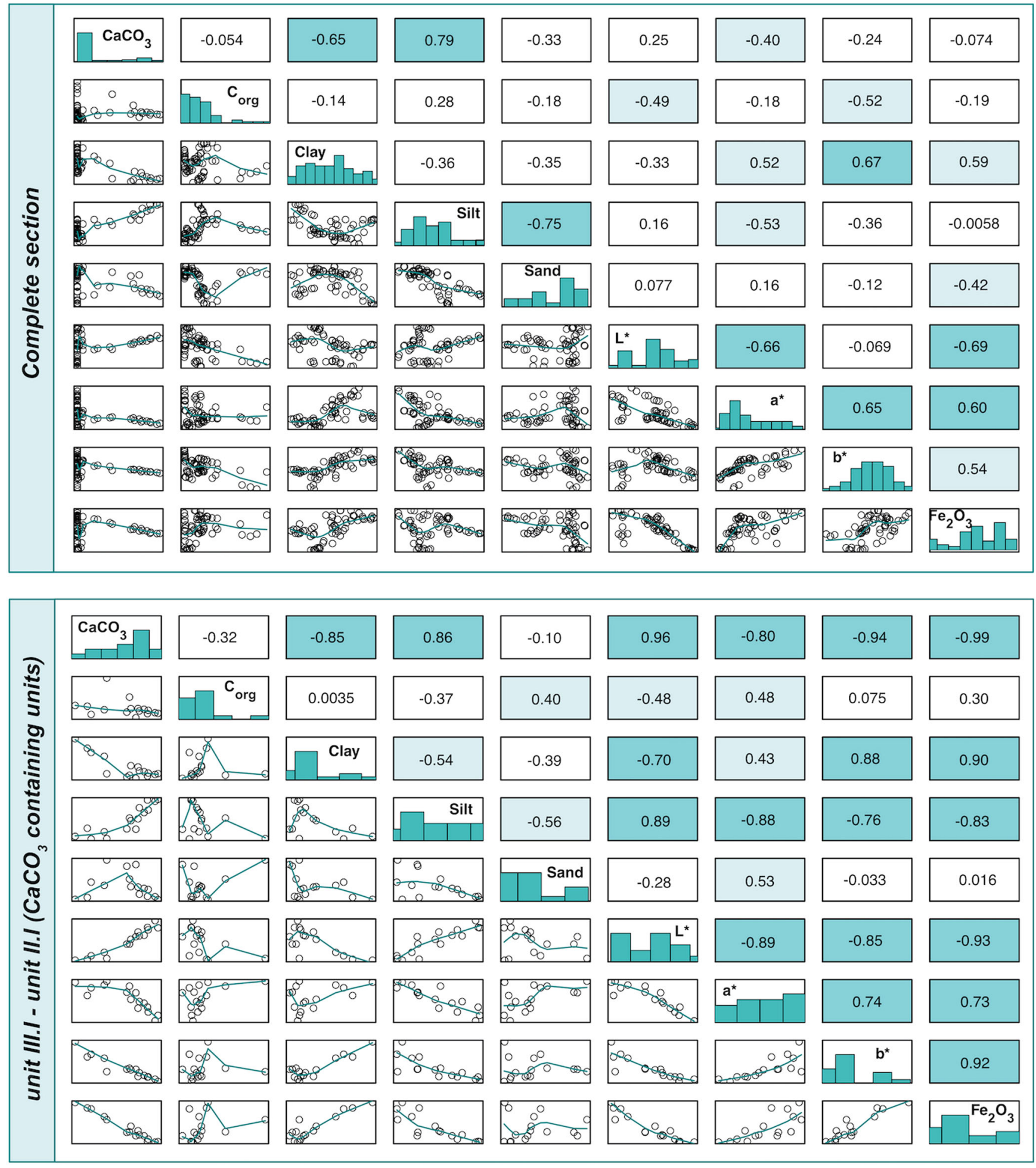

Figure 6. Correlation matrix of $\mathrm{C}_{\text {org, }} \mathrm{CaCO}_{3}$, clay $(<2 \mu \mathrm{m})$, silt $(2-63 \mu \mathrm{m})$, sand (63-2000 $\left.\mu \mathrm{m}\right), \mathrm{CIELAB}$ values, and $\mathrm{Fe}_{2} \mathrm{O}_{3}$. The upper panel shows $\mathrm{r}$ values; the diagonal panel shows the proxy name and histogram; The lower panel shows the $x$ - $y$-distribution of the correlated values. [Color figure can be viewed at wileyonlinelibrary.com]

show the lowest and $\mathrm{L}^{*}$ the highest values within the profile. $\mathrm{CPA}$ and $\mathrm{CIA}$ decrease further but show a small increase at $230 \mathrm{~cm}$ depth. In unit III.III, $\mathrm{Fe}_{2} \mathrm{O}_{3}, \mathrm{a}^{*}$ and $\mathrm{b}^{*}, \mathrm{CIA}$ and $\mathrm{CPA}$ start to increase slowly again while $\mathrm{L}^{*}$ decreases. $\mathrm{C}_{\text {org }}$ shows slight enhances. In unit III.II, $\mathrm{CIA}$ and $\mathrm{CPA}, \mathrm{C}_{\text {org, }} \mathrm{Fe}_{2} \mathrm{O}_{3}$, a* and $\mathrm{b}^{*}$ values increase further, and $\mathrm{L}^{*}$ values deplete. Within unit III.I, the weathering indices $\mathrm{Rb} / \mathrm{Sr}, \mathrm{Ba} / \mathrm{Sr}, \mathrm{C}_{\text {org }}, \mathrm{ClA}$ and CPA decrease once more, notably. At the same time, the $\mathrm{CaCO}_{3}$ content increases for the first time. In unit II, the weathering indices are strongly reduced. On the other hand,
$\mathrm{CaCO}_{3}$ content reaches $30 \%$ within unit II.II. L* values are slightly elevated again, while $\mathrm{Fe}_{2} \mathrm{O}_{3}$, $\mathrm{a}^{*}$ and $\mathrm{b}^{*}$ are slightly reduced in unit II. Within unit I.II, the weathering indices, $\mathrm{Fe}_{2} \mathrm{O}_{3}, \mathrm{a}^{*}$ and $\mathrm{b}^{*}$ increase strongly, $\mathrm{L}^{*}$ shows low values, and $\mathrm{CaCO}_{3}$ is absent. The $\mathrm{C}_{\text {org }}$ content increases by $1.2 \%$ at around $60 \mathrm{~cm}$ depth in unit $I . I /$ before it drops to values similar to those in unit II. In unit I.I, Rb/Sr, CIA, CPA, $\mathrm{Fe}_{2} \mathrm{O}_{3}$, $a^{*}$ and $b^{*}$ are decreasing. $L^{*}$ values are slightly increased but decrease towards the top. $\mathrm{C}_{\text {org }}$ values increase to around $1.5 \%$ at the top. 
Table 1. Analytical results, luminescence results, and calculated ages of the Attenfeld profile

\begin{tabular}{|c|c|c|c|c|c|c|c|c|c|c|c|}
\hline \multirow[b]{2}{*}{ Sample ID } & \multirow[b]{2}{*}{$\begin{array}{l}\text { Sampling } \\
\text { depth } \\
\text { (m b.s.) }\end{array}$} & \multirow[b]{2}{*}{$\begin{array}{l}\text { W } \\
(\%)\end{array}$} & \multirow{2}{*}{$\begin{array}{c}\mathrm{n} \\
\text { accepted/ } \\
\text { measured } \\
\text { aliquots }\end{array}$} & \multicolumn{3}{|c|}{ Radionuclide concentration } & \multirow[b]{2}{*}{$\begin{array}{c}\text { Dose rate } \\
(\mathrm{Gy} / \mathrm{ka})\end{array}$} & \multirow[b]{2}{*}{$\begin{array}{l}\text { RSD } \\
(\%)\end{array}$} & \multirow[b]{2}{*}{$\begin{array}{l}\text { g-value } \\
\text { \%/decade }\end{array}$} & \multirow[b]{2}{*}{$\begin{array}{l}\text { De KFIR } 50 \\
\text { KFpIRIR }_{290} \\
\text { (Gy) }\end{array}$} & \multirow[b]{2}{*}{$\begin{array}{c}\text { Age KFIR } \text { KFo } \\
\text { KFpIRIR } 290 \\
(\mathrm{ka})\end{array}$} \\
\hline & & & & $\begin{array}{c}\cup \\
\text { (ppm) }\end{array}$ & $\begin{array}{c}\text { Th } \\
\text { (ppm) }\end{array}$ & $\begin{array}{c}\mathrm{K} \\
(\%)\end{array}$ & & & & & \\
\hline C-L4238 & 2 & 14 & $13 / 13$ & $2.69 \pm 0.12$ & $11.87 \pm 0.57$ & $1.30 \pm 0.02$ & $3.34 \pm 0.14$ & 4 & & $242.8 \pm 12.5$ & $72.7 \pm 5.0$ \\
\hline C-L4238 & 2 & 14 & $18 / 18$ & $2.69 \pm 0.12$ & $11.87 \pm 0.57$ & $1.30 \pm 0.02$ & $3.19 \pm 0.11$ & 7 & $3.45 \pm 0.27$ & $167.5 \pm 8.8$ & $76.9 \pm 5.4$ \\
\hline C-L4237 & 2.4 & 10 & $16 / 16$ & $3.00 \pm 0.13$ & $11.94 \pm 0.57$ & $1.19 \pm 0.02$ & $3.44 \pm 0.15$ & 5 & & $339.9 \pm 17.5$ & $98.7 \pm 6.7$ \\
\hline C-L4237 & 2.4 & 10 & $19 / 19$ & $3.00 \pm 0.13$ & $11.94 \pm 0.57$ & $1.19 \pm 0.02$ & $3.28 \pm 0.10$ & 10 & $2.99 \pm 0.14$ & $221.8 \pm 12.1$ & $93.6 \pm 6.5$ \\
\hline
\end{tabular}

Dose rate data, equivalent dose values, and luminescence ages. $\mathrm{m}$ b. $\mathrm{s}$. = metres below surface; $\mathrm{KF}=$ potassium feldspar; $U=\mathrm{Uranium}$; Th = Thorium; $K=$ Potassium; age calculation is based on cosmic dose calculation after Prescott and Hutton (1994), conversion factors of Guérin et al. (2011) and the measured sample water content; RSD = relative standard deviation; De = equivalent dose. The internal beta dose rate contribution of the feldspar sample was calculated by assuming a potassium content of $12.5 \pm 0.5 \%$ (Huntley and Baril, 1997 ) and an a-value of $0.12 \pm 0.02$ for pIRIR290 measurements and $0.07 \pm 0.02$ for IR50 measurements. The IR50 age is corrected for fading according to Huntley and Lamothe, 2001).

\section{Correlation of proxies}

Figure 6 shows that no proxy correlates more strongly than $r=0.79\left(\mathrm{CaCO}_{3}\right.$ and silt $)$ with each other when including all values in the calculations. Considering only the units containing $\mathrm{CaCO}_{3}$ (units III.I-II.I), most proxies correlate strongly with each other. Considering $r=|0.4|$ as a mark between not too poorly correlated and somehow correlated, $\mathrm{C}_{\mathrm{org}}$ and sand are an exception, showing correlations between $r=|0.4|$ and $r=1$ 0.56 only with three other proxies $\left(C_{\text {org }}\right.$ with $L^{*}, a^{*}$ and sand; sand further with $\mathrm{a}^{*}$ and silt). Only the correlation of $\mathrm{L}^{*}$ and $\mathrm{C}_{\text {org }}$ is similarly strong $(r=-0.49)$ considering the whole section, where $\mathrm{C}_{\text {org }}$ only shows another correlation above $r=1$ $0.4 \mid$ with $b^{*}(r=-0.52)$. The correlation between sand and silt is stronger with $r=10.75 \mathrm{I}$ and only $\mathrm{Fe}_{2} \mathrm{O}_{3}$ shows another correlation above $r=|0.4|$ with sand $(r=-0.42)$.

\section{Luminescence dating}

Luminescence dating concentrated on $\mathbb{I R}_{50}$ and $\mathrm{pIRIR}_{290}$ stimulation (Fig. 7) for an internal cross-check of the results and to evaluate the resetting of the post-infrared infraredstimulated signal prior to deposition. Prior IR stimulation temperature tests demonstrated that the equivalent dose measured at $290{ }^{\circ} \mathrm{C}$ is independent of a prior IR stimulation temperature of up to $140{ }^{\circ} \mathrm{C}$ (Fig. 8) for samples C-L4237 and C-L4238. Laboratory doses of 370 Gy and 260 Gy were recovered with a ratio of the measured to a given dose of $1.07 \pm 0.01(\mathrm{C}-\mathrm{L} 4037)$ and $1.06 \pm 0.01$ (C-L4038). A fading rate of $3.0 \pm 0.1 \%\left(C-L 4237, I_{50}\right)$ and $3.5 \pm 0.3 \%(C-L 4238$, $\mid R_{50}$ ) was measured. $I R_{50}$ and $p I R I R_{290}$ dating resulted in consistent luminescence ages of $98.7 \pm 6.7 \mathrm{ka}$ and $93.6 \pm 6.5$ ka (C-L4237, pIR $\mathbb{R}_{110} \mid R_{290}$ and fading corrected $I R_{50}$ ) and $72.7 \pm 5.0 \mathrm{ka}$ and $76.9 \pm 5.4 \mathrm{ka}\left(\mathrm{C}-\mathrm{L} 4237, \mathrm{pIR}_{110} \mathrm{IR}_{290}\right.$ and fading corrected $I R_{50}$ ), respectively. Consistent ages from two different luminescence signals that bleach at different rates are a good indicator that the pIRIR 290 signal was completely reset prior to deposition.

\section{Discussion}

\section{Sedimentological indications of environmental fluctuations}

Sedimentological indicators for environmental changes recorded in LPS are always connected to the material composition. Physical and chemical variations within LPS often result from environmental and climatic changes. In unit IV (especially IV.II), the enhanced iron oxide values, redness $\left(a^{*}\right)$, and yellowness $\left(b^{*}\right)$ of the samples, and the low lightness index ( $\left.L^{*}\right)$ (Fig. 5) suggest material leaching. During chemical weathering of minerals (like biotite, olivine, amphibole, pyroxene) iron oxides, especially, are liberated. Those often coat primary minerals, form more or less small iron concretions, and hence contribute to the general brownish appearance of soil material in temperate climate zones (brunification; Amelung et al., 2018). Relatively strong correlations between $\mathrm{L}^{*}, \mathrm{a}^{*}$ and $\mathrm{Fe}_{2} \mathrm{O}_{3}$ values (Fig. 6) are in line with prior studies stating that brunification goes along
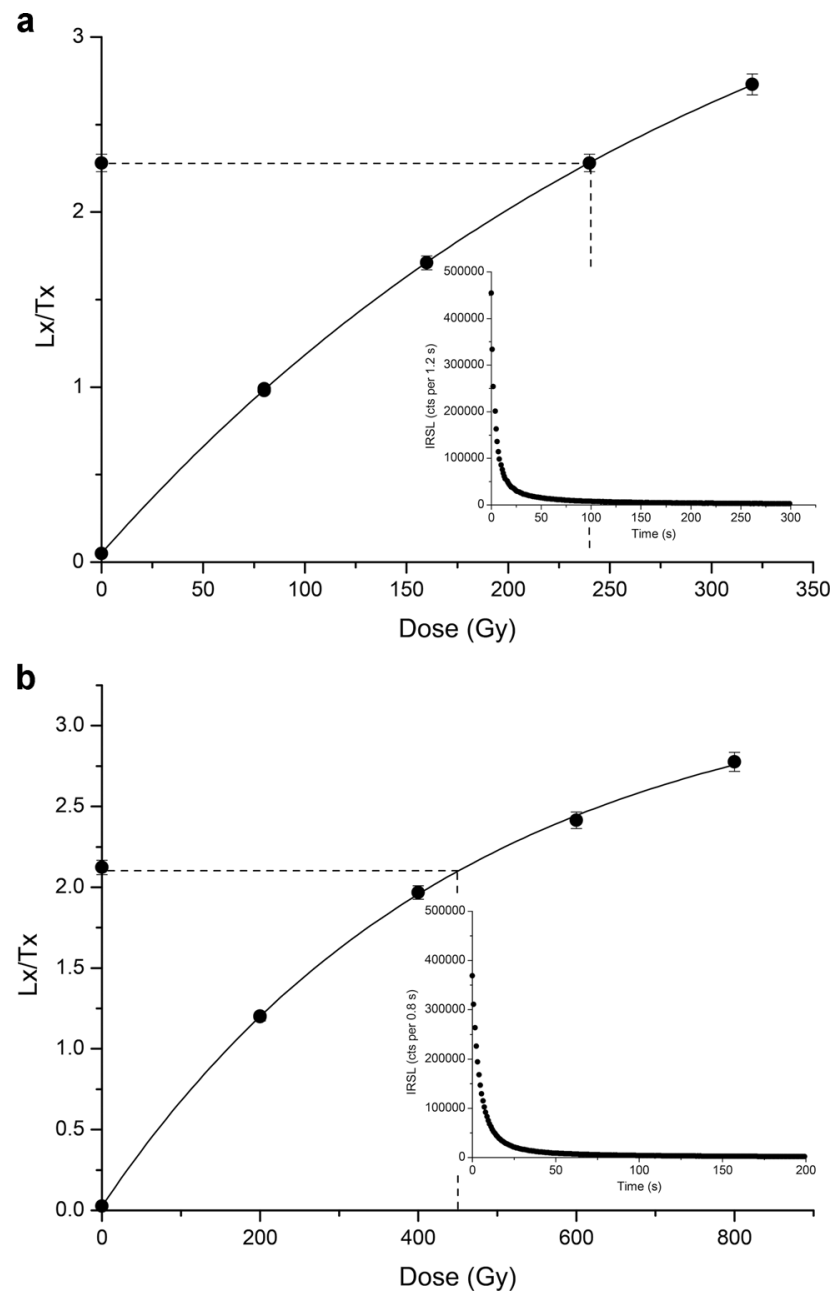

Figure 7. Decay curves and dose response curves of the $I{ }_{50}$ signal (a) and the pIRIR 290 signal (b) of sample C-L4237. 


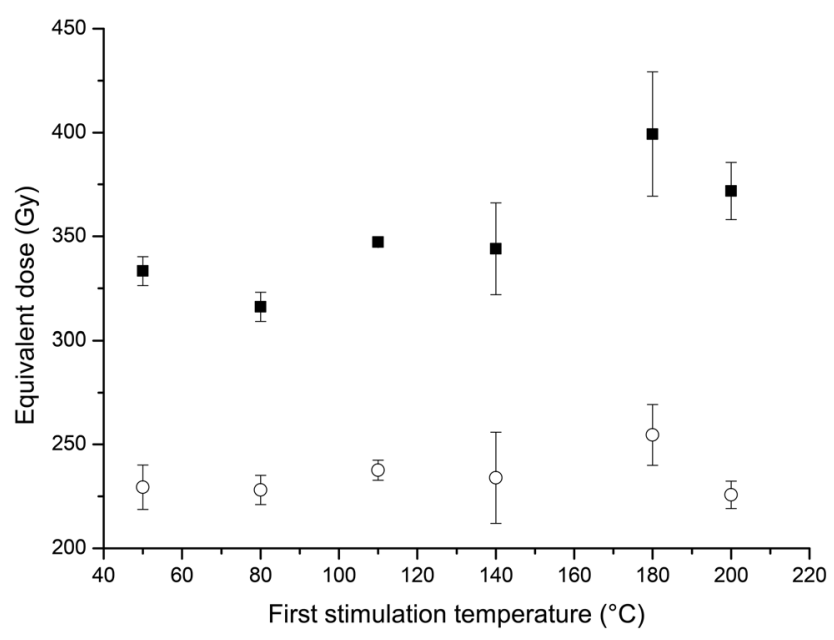

Figure 8. Prior IR stimulation temperature test of samples C-L4237 (filled) and C-L4238 (open). The preheat and pIRIR temperatures were kept constant at $320^{\circ} \mathrm{C} / 290^{\circ} \mathrm{C}$ and the prior IR stimulation temperature was stepwise increased from 50 to $200^{\circ} \mathrm{C}$. The equivalent dose measured at $290^{\circ} \mathrm{C}$ is stable up to a prior IR stimulation temperature of $140{ }^{\circ} \mathrm{C}$.

with an enhanced redness and a darkening of the material compared to pure loess (Schwertmann, 1993; Sprafke, 2016; Vlaminck et al., 2016; Meyer-Heintze et al., 2018). The stronger positive correlations of $\mathrm{b}^{*}$, but also $\mathrm{Fe}_{2} \mathrm{O}_{3}$ and a* values with the clay content further suggest that residues of oxidation formed new minerals, which have a general smaller grain size. The base of the LPS Attenfeld (unit IV, especially IV.I) shows enhanced values of the medium and fine clay fraction and low $\triangle \mathrm{GSD}$ values (Figs 3 and 4). Results of Schulte and Lehmkuhl (2018) imply that low $\triangle \mathrm{GSD}$ values within the medium clay fraction are caused by post-depositional enrichment of secondarily formed minerals. With time and ongoing chemical weathering, the amount of those newly formed clay minerals enhances (loamification; Amelung et al., 2018). In the field, clay coatings in pores and on aggregate surfaces were visibly recognised in unit IV.II (Fig. 2). Those coatings point towards intensive gravitational clay migration (lessivage). As visible in Fig. 2, unit IV.I seems to have experienced reductive processes as well as oxidations. The gradual reduction of clay-sized particles, $\mathrm{Fe}_{2} \mathrm{O}_{3}$, $\mathrm{a}^{*}$ and $\mathrm{b}^{*}$ values, and the lighter material colour along with slight increases of CIA and CPA within unit IV.I might indicate depletion (Figs 3-5). Such strong pedogeneses only occur under interglacial conditions with long periods of warmer and moister environmental settings. When a topsoil (Ah horizon) was rich in silt-sized particles, which can be assumed for the LPS Attenfeld since the palaeosol developed on loess, it is sensitive to slaking (Zech et al., 2014; FAO and IUSS, 2015). In combination with a slope angle $>2^{\circ}$, this can cause extensive erosion (Lehmkuhl et al., 2016). As unit IV.I shows partial mixing with unit III.IV, an erosion of the topsoil seems reasonable (Fig. 2). Similar settings can be observed in other LPS of western Europe where mostly subsoils are preserved, and interglacial palaeosols often as truncated Bt horizons (Terhorst et al., 2001). However, in consideration of the oxidative features in unit IV.I, pedogenic overprinting after the Luvisol formation should be considered. Since interglacials are long phases, soil complexes showing a polygenetic character frequently occur in LPS (Terhorst et al., 2001; Sprafke, 2016; Krauß et al., 2018). Even though the reduction of clay-sized particles, $\mathrm{Fe}_{2} \mathrm{O}_{3}$, a* and $b^{*}$ values, and the lighter material colour along with slight enhancements of CIA and CPA in unit IV.I could speak for an eluvial horizon, the gradual changes might also indicate a further, but less intensive, soil formation or pedogenic overprinting. Overprinting of a Luvisol by less intensive pedogenic processes implies a climatic shift towards cooler temperatures and possible dryer conditions. It cannot be entirely excluded that relocated soil sediment accumulated here, but that would be signalled by abrupt changes in chemical and grain-size composition (Krauß et al., 2016), or pedogenic overprinting would have to be so intense that the signal of soil sediment is completely masked by it. Both options contradict the gradual reduction of chemical weathering and clay-sized particles observed in unit IV.I.

GSI and U-ratio (Fig. 3) are commonly used to identify phases of enhanced input of aeolian material (predominantly silt-sized particles) under cold and dry conditions with increased wind intensities. Higher values are connected to transportation and subsequent accumulation of coarser material compared to phases with lower wind intensities showing lower ratio values (Vandenberghe, 1985; Antoine et al., 2001; Rousseau et al., 2002; Újvári et al., 2016). The GSI and U-ratio signals are only slightly enhanced in units III.IV and III.III, which could be due to minor material weathering. The lack of $\mathrm{CaCO}_{3}$ supports the assumption of at least some sort of leaching (Fig. 5). Nevertheless, CIA, CPA, iron content, colour data, and the low fine and medium clay content suggest that chemical weathering was limited to decalcification only (Figs 3 and 5). The higher $\triangle \mathrm{GSD}$ in unit III.IV (Fig. 4) upholds the conjecture of less leaching of the material (Schulte and Lehmkuhl, 2018). This further indicates that climatic conditions shifted to a colder period.

In the field, the material of unit III.III appeared dark greyish, as visible in Fig. 2. This led to the conjecture that colour differences betweenunit III.III and surrounding units was caused by an higher content of organic matter since a blackish material colour could result from humic material enhancements (Schulze et al., 1993; Konen et al., 2003). However, the $\mathrm{L}^{*}$ only shows a slight darkening of the material and $\mathrm{C}_{\text {org }}$ only small increases in unit III.III (Fig. 5). Since the visible observation (Fig. 2) is barely supported by $\mathrm{C}_{\text {org }}$ and $\mathrm{L}^{*}$, we propose that an A-horizon formation was not extensive. Small increases in clay and iron content suggest marginal loamification processes (Figs 3 and 4), supporting the assumption of only initial soil formation. This implies that vegetation periods were short, resulting in a reduced production of organic matter, but a concurrent climatic shift toward drier conditions also caused a lowered microbial decay of organic matter (Zech et al., 2014; FAO and IUSS, 2015).

The overlying units III.II and III.I seem to have experienced a more substantial material alteration than units III.IV and III.III, as indicated by weathering and colour indices, a finer material composition, and a lower $\triangle$ GSD. Still, pedogenic processes do not appear as extensive as in unit IV (Figs 3-5). This might be connected to interstadial rather than interglacial climatic conditions with lower temperatures and drier soil-moisture regimes, causing less material alteration and weaker soil development resulting in the formation of polygenetic Bw horizons in units III.II and III.I (Kadereit et al., 2013; Terhorst et al., 2015; Prud'homme et al., 2015, 2016; Sauer et al., 2016; Sprafke, 2016; Meyer-Heintze et al., 2018). The sudden disappearance of medium and coarse sand-sized particles between around $145 \mathrm{~cm}$ and $170 \mathrm{~cm}$ depth at the upper part of unit III.II, which make up 8 to $5 \%$ of the grain-size composition above and below, might indicate fresh input of loess material. The colour data, chemical composition, and weathering indices do not show abrupt changes (Fig. 5). The U-ratio and GSI are lowest within this part and do not indicate noticeably higher input of airborne material as well (Fig. 3). More or less pure loess layers of the Upper Pleistocene show a modal peak between $30 \mu \mathrm{m}$ and $40 \mu \mathrm{m}$ in most western European sequences (Krauß et al., 2018). But in unit III.II are 
no pronounced gains within the class of lower coarse silt. Increases are mostly recognisable within the grain-size range of fine silt to middle clay. If assuming fresh input of loess, the pedogenic processes must have been so strong that they completely masked the aeolian signal. Since pedogenic indicators do not reflect such strong pedogenesis here either, we conclude that fresh input of airborne material, if occurred, must have been marginal.

Above, unit II shows up to around $30 \% \mathrm{CaCO}_{3}$ content (Fig. 5), suggesting low leaching of material. This might be connected to colder and dryer conditions during the time of accumulation (Vandenberghe, 1985; Antoine et al., 2001; Rousseau et al., 2002; Frechen et al., 2003; Lehmkuhl et al., 2016; Újvári et al., 2016). The higher GSI and U-ratio values (Fig. 3) further suggest higher accumulation rates with reduced leaching (Vandenberghe et al., 1997; Antoine et al., 2001). Nevertheless, the substantial decrease of chemical weathering indices $(\mathrm{Rb} / \mathrm{Sr}, \mathrm{Ba} / \mathrm{Sr}, \mathrm{CIA}, \mathrm{CPA})$ in unit I/ (Fig. 5) has to be reviewed with caution since the material contains $\mathrm{CaCO}_{3}$, while the other units, including unit III.IV, do not. Even though the presence of $\mathrm{CaCO}_{3}$ already speaks for less leaching of the material, it can affect the accuracy of weathering indices. Figure 6 clearly shows that $\mathrm{CaCO}_{3}$ is strongly correlated to most parameters within the carbonate-containing units and is only correlated to clay and silt in the context of the whole sequence. Buggle et al. (2011) point out that the CPA is insensitive to those impacts. However, they further state that secondary carbonate dynamics influence the weathering indices based on $\mathrm{Sr}(\mathrm{Ba} / \mathrm{Sr}, \mathrm{Rb} / \mathrm{Sr})$. The substitution of carbonate Ca by $\mathrm{Sr}$ can partly mask the initial $\mathrm{Rb} / \mathrm{Sr}$ and $\mathrm{Ba} / \mathrm{Sr}$ ratios, causing an underestimation of weathering intensity. Weathering indices based on calculated $\mathrm{CaO}^{*}$, like $\mathrm{CIA}$, may suffer uncertainties concerning the separation of carbonate $\mathrm{Ca}$ from silicate $\mathrm{Ca}$, resulting in an underestimation of weathering intensity of carbonate-containing material. Subsequently, most weathering indices are most valuable in carbonate-free material (Buggle et al., 2011). Still, despite the data suggesting less weathering of the material and colder and dryer conditions during sediment accumulation, the layering observed in the field indicates partial physical and chemical alteration of the material, at least to a small extent. The embedded layers of weathered material (units II.III and II.I) point to fluctuations of reductive and oxidative conditions. Repeated thawing of permafrost combined with poor drainage usually causes those conditions (Van Vliet-Lanoë, 1989, 1998; Antoine et al., 2001, 2009b; Terhorst et al., 2015). Further, the penetration of unit II material into unit III is similar to the border between units $I V$ and III.II, which suggests that comparable solifluction processes took place. The wavy layering might be connected to erosional events.

The uppermost unit I seems to reflect a Holocene soil development, including signs of anthropogenic cultivation of today's soils visible by a typical, ploughed A-horizon with a sharp horizon border at around $20 \mathrm{~cm}$ depth (Fig. 2; Ap; unit I.I). All proxies indicate intense weathering. However, the indications of decreased chemical weathering in unit I.I compared to unit I.II are connected to its topsoil character with a higher content of organic matter, causing low $L^{*}$ values, and the reduced content of clay minerals (Figs 3-5; Amelung et al., 2018). Yet, the $L^{*}$ values are lowest in unit I.II even though $\mathrm{C}_{\mathrm{org}}$ shows the highest values in unit I.I. A correlation of $L^{*}$ and $C_{\text {org }}(r=-0.49)$ suggests that $C_{\text {org }}$ might not be the only proxy influencing the material's lightness. Spielvogel et al. (2004) identified a significant relationship between aryl $\mathrm{C}$ and $\mathrm{L}^{*}$ of $\mathrm{r}=-0.87$ but only below $\mathrm{r}=-0.4$ correlations with other organic $\mathrm{C}$ components. They further state that the material's lightness is affected by the $\mathrm{CaCO}_{3}$ content and the soil texture since clay and silt particles reflect more light than sand. Figure 6 supports the assumption of $\mathrm{CaCO}_{3}$ influencing material colour since there is a strong correlation between $\mathrm{CaCO}_{3}$ with finer grain sizes and CIELAB values in $\mathrm{CaCO}_{3-}^{-}$ containing units. These factors can lead to misinterpretations of $\mathrm{C}_{\mathrm{org}}$ estimations solely based on the lightness of the material. The peak of $\mathrm{C}_{\mathrm{org}}$ at around $60 \mathrm{~cm}$ depth (Fig. 5) can be explained by assuming a burrow filled with A-horizon material where the sample was taken. In Fig. 2, the picture of the upper sequence shows such bioturbations within the horizon (unit I.II).

\section{The chronostratigraphic context for palaeoenvironmental dynamics - implications of recent findings}

The data discussed above (Sedimentological indications of environmental fluctuations) suggest that unit IV.II is a welldeveloped $\mathrm{Bt}$ horizon of a truncated palaeo-Luvisol likely connected to an interglacial phase of minimum MIS 5e age (Table 1 and Fig. 9), as also suggested by Jerz (1993) in Attenfeld. As chemical weathering and biological activity are regulated by temperature and humidity (Sprafke et al., 2014), the overall climatic trend of decreasing temperatures and soil moisture towards the end of MIS 5e might have caused less intense pedogenic overprinting in unit IV.I, resulting in its polygenetic characteristics. Decreasing temperature trends with extending periods of soil and sediment freezing during Early Glacial (MIS 5d-a) may have initiated solifluction, as indicated by the interlocking of unit IV.I and the overlying decalcified loess layer (unit III.IV).

As marked by Marković et al. (2015), luminescence chronology might be too imprecise to correlate preserved short-span dust events in LPS to specific events recorded in high-resolution records like Greenland ice cores. Nevertheless, the age estimate of sample C-L4237 (pIRIR 290 : $98.7 \pm 6.7 \mathrm{ka}$ and $\mathrm{IR}_{50}: 93.6 \pm 6.5 \mathrm{ka}$; Table 1) suggests that the deposition of unit III.IV is connected to at least one of the dust events during the Early Glacial's short cooling phases (most likely MIS 5d; Kukla, 1977; Rousseau et al., 2013; Marković et al., 2015). In most German regions, the Early Glacial is not preserved, and early MIS 4 is documented as mixed material containing loess and Eemian soil material (Niedereschbach Zone, Fig. 9; Rohdenburg and Meyer, 1979; Semmel, 1989; Meszner et al., 2013). Developed under more continental climate conditions, the LPS Dolní Věstonice (Czech Republic) is among the LPS that include a wellpreserved record of MIS 5d-a in Europe (Klima et al., 1962; Musson and Wintle, 1994; Cilek, 1999; Frechen et al., 1999; Zander, 2000; Antoine et al., 2013). The so-called marker silts (Kukla, 1977) preserved here are thin layers of aeolian material that Rousseau et al. (2013) connected to specific dust events during cooling phases recorded in the Greenland ice cores. Since our numerical chronology is based on two OSL age estimates, a connection with a particular marker horizon might be too enthusiastic for unit III.IV. However, the Early Glacial association is further supported by the dark greyish layer's occurrence above (unit III.III, Fig. 2). Typically, A/C-soil developments and loess accumulation alternated during the Early Glacial (Kukla, 1977; Rousseau et al., 2013). The formation of $\mathrm{A} / \mathrm{C}$-soils during the more temperate phases corresponds to a dry steppe climate with short vegetation periods, both limiting the formation and microbial decay of organic matter (Bibus et al., 2002; Techmer et al., 2006; Zech et al., 2014; Terhorst et al., 2015). Jerz (1993) did not explicitly relate the loess layer (unit III.IV) to a specific known unit but seemingly considered an MIS 4 age (approximately 71-57 ka). This appears to be unlikely considering our present results. 


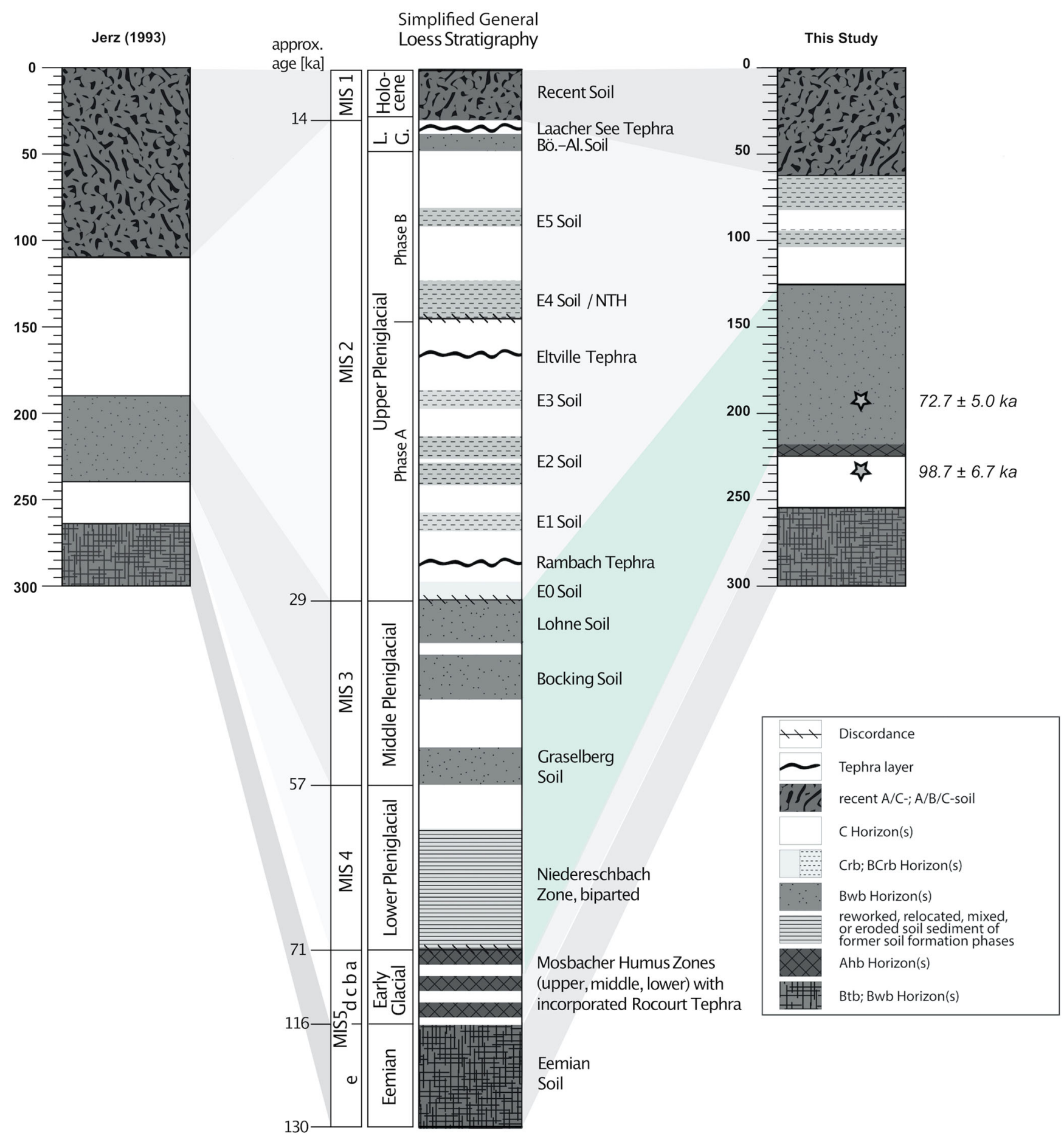

Figure 9. Possible correlation of the recent findings in Attenfeld to Jerz (1993) and Upper Pleistocene loess stratigraphy in Germany (approx. ages based on Lisiecki and Raymo, 2005; modified after Zens et al., 2017; refined after Schönhals et al., 1964 and Bibus et al., 2002). [Color figure can be viewed at wileyonlinelibrary.com]

To get an estimate of when the material accumulated, in which the presumed MIS 3 Lohne Soil developed (Jerz, 1993), we took the second OSL sample in unit III.II. The age estimate of sample C-L4238 (pIRIR $290: 72.7 \pm 5.0 \mathrm{ka}$ and $\mathrm{IR}_{50}$ : $76.9 \pm 5.4 \mathrm{ka}$; Table 1 and Fig. 9) offers more than one possible interpretation of the palaeoenvironmental dynamics. Firstly, the age estimate C-L4238 provides evidence for sedimentation at the end of the Early Glacial (MIS 5a; Lisiecki and Raymo, 2005). Terrestrial systems may react with an offset in time and with an influence of the local surrounding to global changes, but regarding the age estimate of sample C-L4238, at most, an early MIS 4 age for the accumulation of unit III.II within the sample's surrounding might be possible.
As already mentioned, early- to mid-MIS 4 was characterised by reworked loess material and admixed Eemian soil sediment in most western European sequences, but reworked Eemian soil sediment within unit III.II was not detected in this study. Therefore, sediment accumulation is assumed to be connected to the Early Glacial (MIS 5a) in the following discussion.

As discussed above (Sedimentological indications of environmental fluctuations), the data might indicate polygenetic soil developments in unit III.II with less weathering at the bottom and stronger processes at the top (Figs 3-5). Another interpretation of unit III.II could be that decreasing pedogenesis with depth caused notable differences between the upper and lower part of the unit. 
Therefore, we present three possible scenarios concerning the soil formation of unit III.II.

(1) Terhorst et al. (2015) state that well-developed palaeoCambisols $(\mathrm{Bw})$ are regarded as characteristic marker horizons of MIS 3, with the Lohne Soil being the youngest, most important, and most developed interstadial soil, and give an overview of conducted research on age estimates of the Lohne Soil. Kadereit et al. (2013) conclude that the Lohne Soil developed within the time window of GIS 7 to 5 (Greenland interstadials 7-5: 36-32 ka) in Nussloch, and Sauer et al. (2016) connected the Lohne Soil formation to a time window of GIS 4 to 3 ( 29-27 ka) in Datthausen (Swabia; $150 \mathrm{~km}$ upstream the Danube River, west of Attenfeld). Terhorst et al. (2015) state that a Lohne Soil equivalent was dated to $29.1 \pm 2.6 \mathrm{ka}$ (OSL) in Upper Austria. The parent material of an older MIS 3 Cambisol, the Böckingen Soil, is frequently dated to about $45 \mathrm{ka}$ in Germany and Austria (Frechen, 1999; Bibus et al., 2002; Terhorst et al., 2002).

(2) A further possible interpretation would be that unit III.II might be an equivalent to the iso-humic soil 4 (IHS 4; Antoine et al., 2013, 2016) found in Dolní Věstonice, as direct age determination indicated an age of $71.3 \pm 4.9 \mathrm{ka}$ for that layer (Fuchs et al., 2013). In Dolní Věstonice, the IHS 4 appears as homogeneous dense grey-brownish sandy silt with a fine fraction $(<6 \mu \mathrm{m})$ of $19 \%$ and a fine sand $(61-150 \mu \mathrm{m})$ content of $>21 \%$ (Antoine et al., 2013, 2016). In Attenfeld, unit III.II contains more than $35 \%$ fine fraction $(<6.3 \mu \mathrm{m})$, the fine sand $(63-200 \mu \mathrm{m})$ content varies between 8 and $12 \%$ (Fig. 3), and the sediment did not appear to be greyish but relatively light brownish. This might be connected to an enhanced soil-moisture regime in Attenfeld compared to the more continental-situated Dolní Věstonice section. More extensive weathering may have resulted in a higher clay content and higher iron oxide values, causing a rather brown appearance of the material. More substantial weathering of the material compared to the Dolní Věstonice section $\left(>5 \% \mathrm{CaCO}_{3}\right)$ would also explain the absence of $\mathrm{CaCO}_{3}$ within most of unit III (Fig. 5).

(3) As a third option and combination of scenarios (1) and (2), unit III.II might be a result of several soil formations between MIS 5a and the end of MIS 3 (Terhorst et al., 2015). A prior late Early Glacial soil formation (2) could have been pedogenically overprinted during one or more interstadials during MIS 3 (1). Although it is possible that an MIS 3 soil developed in loess sediment, which has been deposited during the late Early Glacial (C-L4238: pIRIR 290 : $72.7 \pm 5.0$ $\mathrm{ka}$ and $\mathrm{IR}_{50}: 76.9 \pm 5.4 \mathrm{ka}$ ), it is unlikely that between deposition and possible MIS 3 soil formation(s) the material was not altered in any way.

As discussed above (Sedimentological indications of environmental fluctuations), unit II appears to be connected to glacial phases with high accumulation rates and strongly reduced leaching of loess, highly likely during MIS 2 . The two embedded layers units II.III and II.I support that assumption, as similar weekly developed MIS 2 tundra gleys are widely preserved in western European LPS (Erbenheimer Soils, Fig. 9; Lehmkuhl et al., 2016).

In summary, the profile shows partly intense phases of erosion and reworking, which might be associated with more humid soil-moisture regimes and a slope angle $>2^{\circ}$. Furthermore, field observation, sediment characteristics, and age estimates do not entirely support pre-existing chronostratigraphies (Fig. 9). Thus, they indicate that prior interpretations might be too simple to sufficiently represent the Attenfeld
LPS. Our results suggest that the section shows a stratigraphy as follows (bottom to top): (A) two soil horizons possibly connected to MIS 5e; (B) one yellowish loess layer and a small dark greyish layer connected to MIS 5d-c (C-L4237, pIRIR 290 : $98.7 \pm 6.7 \mathrm{ka}$ and $\left.I_{50}: 93.6 \pm 6.5 \mathrm{ka}\right)$; (C) a light brownish soil complex that might be related to (1) MIS 3 soil formation(s), (2) MIS 5a soil formation(s), or (3) pedogenic overprinting of MIS 5a soil material during MIS 3 (C-L4238: pIRIR 290 : $72.7 \pm 5.0 \mathrm{ka}$ and $I_{50}: 76.9 \pm 5.4 \mathrm{ka}$ ); (D) a more or less unweathered loess package with two embedded minor weathered layers possibly of MIS 2 age; and (E) a Holocene soil at the top. As a consequence of our results, it is not possible to provide unassailable statements concerning environmental conditions during MIS 3 when $\mathrm{AMH}$ dispersed along the Danube corridor since we cannot confirm or reject MIS 3 soil development(s) in Attenfeld.

\section{Conclusion}

Our study aimed to provide state-of-the-art insights into the palaeoenvironmental dynamics throughout the Upper Pleistocene in Bavaria along the Danube River by investigating the Attenfeld LPS with a multi-proxy approach. We pointed out that the preserved situation in Attenfeld is interpretable in various ways and demonstrated how strongly LPS are sensitive to environmental settings and dynamics. Within the lower part of the sequence, the two OSL age estimates, combined with field observations and sediment characteristics, suggest Early Glacial loess input and possible Early Glacial pedogenesis (MIS $5 \mathrm{~d}-\mathrm{c}$ and MIS $5 \mathrm{a}$ ). We further found indications for polygenetic characteristics within the presumed Eemian soil complex and established three possible scenarios for the formation of the previously postulated MIS 3 soil. The light brownish soil complex might be related to (1) MIS 3 soil formation(s), (2) MIS 5a soil formation(s), or (3) pedogenic overprinting of MIS 5a soil material during MIS 3, which can be considered as the most likely scenario. Although it is possible that an MIS 3 soil complex developed in late Early Glacial loess sediments, it is unlikely that between sediment deposition and possible MIS 3 soil formation(s), the material was not altered in any way. Thus, our findings draw a more complex picture of environmental dynamics than previous studies suggested and stand partly in contrast with those pre-existing interpretations. Hence, we conclude that prior stratigraphies might be too simple to represent the Attenfeld section adequately. As further age estimates were not generated, some questions concerning MIS 4-2 environmental dynamics are not completely solved by the present study. Therefore, we suggest further investigations on LPS in southern Bavaria for creating a robust chronostratigraphic composite of the region's environmental dynamics throughout the last interglacial-glacial cycle.

Acknowledgements. The project was funded by the Deutsche Forschungsgemeinschaft (DFG, German Research Foundation) Project number 57444011 - CRC 806 'Our way to Europe', subproject D1 'Analysis of Migration Processes due to environmental conditions between 40000 and 14000 a B in the Rhine-Meuse Area'. We thank Thomas Hauck and Bernhard Buhs for their support during the field campaign. We thank Marianne Dohms for her help with laboratory analysis. Special thanks go to our student co-workers for helping with laboratory work. We thank the reviewers and the editors. Their thorough reviews and critical remarks helped us to improve the manuscript. Open Access funding enabled and organized by Projekt DEAL. 


\section{Data availability statement}

Sedimentological and geochemical data connected to the study have been uploaded to https://www.pangaea.de/ and will be accessible to the public once accepted.

\section{References}

Allen JRL, Thornley DM. 2016. Laser granulometry of Holocene estuarine silts: effects of hydrogen peroxide treatment. The Holocene 14: 290-295.

Amelung W, Blume H-P, Fleige H et al. 2018. Scheffer/Schachtschabel Lehrbuch der Bodenkunde. Springer: Berlin, Heidelberg.

Antoine P, Rousseau D-D, Zöller L et al. 2001. High-resolution record of the last Interglacial-glacial cycle in the Nussloch loess-palaeosol sequences, Upper Rhine Area, Germany. Quaternary International 76-77: 211-229.

Antoine P, Rousseau D-D, Fuchs M et al. 2009a. High-resolution record of the last climatic cycle in the southern Carpathian Basin (Surduk, Vojvodina, Serbia). Quaternary International 198: 19-36.

Antoine P, Rousseau D-D, Moine O et al. 2009b. Rapid and cyclic aeolian deposition during the Last Glacial in European loess: a highresolution record from Nussloch, Germany. Quaternary Science Reviews 28: 2955-2973.

Antoine P, Rousseau D-D, Degeai J-P et al. 2013. High-resolution record of the environmental response to climatic variations during the Last Interglacial-Glacial cycle in Central Europe: the loesspalaeosol sequence of Dolní Věstonice (Czech Republic). Quaternary Science Reviews 67: 17-38.

Antoine P, Moine O, Rousseau D-D et al. 2016. II. Loess-Palaeosol sequence DV-09 (Dolni Vestonice Brickyard). Chronostratigraphy and palaeoenvironments 49-61.

Auclair M, Lamothe M, Huot S. 2003. Measurement of anomalous fading for feldspar IRSL using SAR. Radiation Measurements 37: 487-492.

Bayerisches Landesamt für Umwelt. 2020. Geologische Karte 1:25.000 - No. 7133 (Eichstätt), 7233 (Neuburg a.d. Donau), 7134 (Gaimersheim), 7234 (Ingolstadt) [WWW Document]. URL https:// www.Ifu.bayern.de/geologie/geo_karten_schriften/gk25/index.htm (accessed 10.1.20).

Becker-Haumann R, Frechen M. 1997. Vergleichende LumineszenzDatierungen mit IRSL und TL am Deckschichtenprofil Bobingen/ Lechtal. Zeitschrift für Geologische Wissenschaften 25: 617-634.

Bibus E. 1995. Äolische Deckschichten, Paläoböden und Mindestalter der Terrassen in der Iller-Lech-Platte. Geolgica Bavarica 99: 135-164.

Bibus E, Rähle W, Wedel J. 2002. Profilaufbau, Molluskenführung und Parallelisierungsmöglichkeiten des Altwürmabschnitts im Lössprofil Mainz-Weisenau. E\&G Quaternary Science Journal 51: 1-14.

Bibus E, Frechen M, Kösel M et al. 2007. Das jungpleistozäne Lößprofil von Nußloch (SW-Wand) im Aufschluss der Heidelberger Zement AG. E\&G Quaternary Science Journal 56: 227-255.

Bleich K. 1989. Gliederung und Untergrund der Lößabfolge von Attenfeld, Lkr. Neuburg-Schrobenhausen. In Steinzeitliche Kulturen an Donau und Altmühl, Rieder $\mathrm{KH}$ (ed.). Begleitband zur Ausstellung im Stadtmuseum Ingolstadt: 13-14.

Blott SJ, Pye K. 2012. Particle size scales and classification of sediment types based on particle size distributions: Review and recommended procedures. Sedimentology 59: 2071-2096.

de Boer GB, de Weerd C, Thoenes D et al. 1987. Laser diffraction spectrometry: Fraunhofer diffraction versus Mie scattering. Particle Characterization 4: 14-19.

Brennan BJ. 2003. Beta doses to spherical grains. Radiation Measurements 37: 299-303.

Brunnacker K. 1953. Der würmeiszeitliche Löß in Südbayern. Geologica Bavarica 19: 258-265.

Buggle B, Glaser B, Hambach $U$ et al. 2011. An evaluation of geochemical weathering indices in loess-paleosol studies. Quaternary International 240: 12-21.

Buurman P, Pape T, Reijneveld JA et al. 2001. Laser-diffraction and pipette-method grain sizing of Dutch sediments: correlations for fine fractions of marine, fluvial, and loess samples. Netherlands Journal of Geosciences 80: 49-57.
Buylaert J-P, Jain M, Murray AS et al. 2012. A robust feldspar luminescence dating method for Middle and Late Pleistocene sediments. Boreas 41: 435-451.

Cilek V. 1999. Mineralogy of the clastic fraction of Dolni Vestonice loess profile (Southern Moravia, Czech Republic). In Terestrische Quartärgeologie, Becker-Haumann R, Frechen M (eds). Köln: Logabook; 161-176.

Cullers RL. 2000. The geochemistry of shales, siltstones and sandstones of Pennsylvanian-Permian age, Colorado, USA: implications for provenance and metamorphic studies. Lithos 51: 181-203.

Eckmeier E, Egli M, Schmidt MWI et al. 2010. Preservation of firederived carbon compounds and sorptive stabilisation promote the accumulation of organic matter in black soils of the Southern Alps. Geoderma 159: 147-155.

FAO and IUSS. 2015. World reference base for soil resources 2014: International soil classification system for naming soils and creating legends for soil maps - Update 2015 World Soil Resources Reports. FAO: Rome.

Fischer P, Jöris O, Fitzsimmons KE et al. 2021. Millennial-scale terrestrial ecosystem responses to Upper Pleistocene climatic changes: 4D-reconstruction of the Schwalbenberg LoessPalaeosol-Sequence (Middle Rhine Valley, Germany). CATENA 196 104913. https://doi.org/10.1016/j.catena.2020.104913

Floss H, Fröhle S, Wettengl S. 2016. The Aurignacian along the Danube. Its Two-Fold Role as a Transalpine and Cisalpine Passageway of Early Homo Sapiens into Europe. Presented at the Southeast Europe Before Neolithisation. Proceedings of the International Workshop within the Collaborative Research Centres sfb;13-39.

Frechen M. 1999. Upper Pleistocene loess stratigraphy in Southern Germany. Quaternary Science Reviews 18: 243-269.

Frechen M, Oches EA, Kohfeld KE. 2003. Loess in Europe-mass accumulation rates during the Last Glacial Period. Quaternary Science Reviews 22: 1835-1857.

Frechen M, Zander A, Cílek V et al. 1999. Loess chronology of the Last Interglacial/Glacial cycle in Bohemia and Moravia, Czech Republic. Quaternary Science Reviews 18: 1467-1493.

Frechen M, Schirmer W. 2011. Luminescence Chronology of the Schwalbenberg II Loess in the Middle Rhine Valley. E\&G Quaternary Science Journal 60: 6.

Fuchs M, Kreutzer S, Rousseau D-D et al. 2013. The loess sequence of Dolní Věstonice, Czech Republic: A new OSL-based chronology of the Last Climatic Cycle. Boreas 42: 664-677.

Gocke M, Hambach U, Eckmeier E et al. 2014. Introducing an improved multi-proxy approach for paleoenvironmental reconstruction of loess-paleosol archives applied on the Late Pleistocene Nussloch sequence (SW Germany). Palaeogeogr,aphy Palaeoclimatology, Palaeoecology 410: 300-315.

Guérin G, Mercier N, Adamiec G. 2011. Dose-rate conversion factors: update. Ancient TL 29: 5-8.

Haidle MN, Pawlik AF. 2010. The earliest settlement of Germany: Is there anything out there? Quaternary International 223-224: 143-153.

Hauck TC, Lehmkuhl F, Zeeden C et al. 2018. The Aurignacian way of life: Contextualizing early modern human adaptation in the Carpathian Basin. Quaternary International 485: 150-166.

Huntley DJ, Baril M. 1997. The K content of the K-feldspars being measured in optical dating or in thermoluminescence dating. Ancient TL 15: 11-13.

Huntley DJ, Lamothe M. 2001. Ubiquity of anomalous fading in K-feldspars and the measurement and correction for it in optical dating. Canadian Journal of Earth Sciences 38: 1093-1106.

ISO 10693, N. 1995. Soil Quality-Determination of Carbonate Content-Volumetric Method.

ISO 11277. 2002. Soil quality-Determination of particle size distribution in mineral soil material-Method by sieving and sedimentation (ISO 11277:1998 + ISO 11277:1998 Corrigendum $1: 2002)$.

ISO 13320. 2020. Particle size analysis — Laser diffraction methods

ISO 13320-1, B. 1999. Particle size analysis-Laser diffraction methodsPart 1: General principles.

ISO 14688-1, E. 2002. Geotechnical investigation and testing-Identification and classification of soil - Part 1: Identification and description. 
Jerz H. 1993. Das Eiszeitalter in Bayern - Erdgeschichte - Gesteine Wasser - Boden, Geologie von Bayern. Schweizerbart'sche Verlagsbuchhandlung (Nägele u. Obermiller): Stuttgart.

Jerz H, Grottenthaler W. 1995. Quartärprofile mit Paläoböden in Südbayern. Geologica Bavarica 179-185.

Jerz H, Kemp RA, Grottenthaler W. 1993. Bodenkundliche Untersuchungen an der Artefaktfundstelle Attenfeld. Das archäologische Jahr in Bayern 1992: 29-31.

Kadereit A, Kind C-J, Wagner GA. 2013. The chronological position of the Lohne Soil in the Nussloch loess section - re-evaluation for a European loess-marker horizon. Quaternary Science Reviews 59: 67-86.

Kels H. 2007. Bau und Bilanzierung der Lössdecke am westlichen Niederrhein (Dissertation). https://docserv.uni-duesseldorf.de/servlets/ DocumentServlet?id=3628

Kels H, Schirmer W. 2011. Relation of loess units and prehistoric find density in the Garzweiler open-cast mine. Lower Rhine. E\&G Quaternary Science Journal 59: 59-65.

Klasen N, Fischer P, Lehmkuhl F et al. 2015. Luminescence dating of loess deposits from the Remagen-Schwalbenberg site, Western Germany. Geochronometria 42.

Klima B, Kukla J, Lozek V et al. 1962. Stratigraphie des Pleistozäns und Alter des paläolithischen Rastplatzes in der Ziegelei von Dolní Vestonice (Unter-Wisternitz). Anthropozoikum 11: 93-145.

Konen ME, Burras CL, Sandor JA. 2003. Organic Carbon, Texture, and Quantitative Color Measurement Relationships for Cultivated Soils in North Central lowa. Soil Science Society of America Journal 67: 1823-1830.

Krauß L, Zens J, Zeeden C et al. 2016. A Multi-Proxy Analysis of two Loess-Paleosol Sequences in the Northern Harz Foreland, Germany. Palaeogeography, Palaeoclimatology, Palaeoecology 461: 401-417.

Krauß L, Kappenberg A, Zens J et al. 2018. Reconstruction of Late Pleistocene paleoenvironments in southern Germany using two high-resolution loess-paleosol records. Palaeogeography, Palaeoclimatology, Palaeoecology 509: 58-76.

Kukla GJ. 1977. Pleistocene land-sea correlations I. Europe. EarthScience Reviews 13: 307-374.

Lehmkuhl F, Zens J, Krauß L et al. 2016. Loess-paleosol sequences at the northern European loess belt in Germany: Distribution, geomorphology and stratigraphy. Quaternary Science Reviews 153: 11-30.

Lehmkuhl F, Nett JJ, Pötter S et al. 2020. Loess landscapes of Europe Mapping, geomorphology, and zonal differentiation. Earth-Science Reviews 215: 103496.

Lisiecki LE, Raymo ME. 2005. A Pliocene-Pleistocene stack of 57 globally distributed benthic $\delta 18 \mathrm{O}$ records. Paleoceanography and Paleoclimatology 20: PA1003.

Marković SB, Stevens T, Kukla GJ et al. 2015. Danube loess stratigraphy - Towards a pan-European loess stratigraphic model. Earth-Science Reviews 148: 228-258.

Mayr C, Matzke-Karasz R, Stojakowits P et al. 2017. Palaeoenvironments during MIS 3 and MIS 2 inferred from lacustrine intercalations in the loess-palaeosol sequence at Bobingen (southern Germany). E\&G Quaternary Science Journal 66: 73-89.

McLennan SM. 1993. Weathering and Global Denudation. Journal of Geology 101: 295-303.

Mejdahl V. 1979. Thermoluminescence dating: beta-dose attenuation in quartz grains. Archaeometry 21: 61-72.

Meszner S, Kreutzer S, Fuchs M et al. 2013. Late Pleistocene landscape dynamics in Saxony, Germany: Paleoenvironmental reconstruction using loess-paleosol sequences. Quaternary International 296: 94-107.

Meyer-Heintze S, Sprafke T, Schulte $P$ et al. 2018. The MIS 3/2 transition in a new loess profile at Krems-Wachtberg East - A multimethodological approach. Quaternary International 464: 370-385.

Muhs DR. 2007. Loess deposits, origins and properties. In Encyclopedia of Quaternary Science, Elias S (ed). Elsevier, 1405-1418.

Musson FM, Wintle AG. 1994. Luminescence dating of the loess profile at Dolní Vestonice, Czech Republic. Quaternary Science Reviews 13: 411-416.

Nelson MS, Gray HJ, Johnson JA et al. 2015. User guide for luminescence sampling in archaeological and geological contexts. Advances in Archaeological Practice 3: 166-177.

Nesbitt, H. \& Young, G.(1982) Early Proterozoic climates and plate motions inferred from major element chemistry of lutites. Nature, 299: 715-717. https://doi.org/10.1038/299715a0
Özer M, Orhan M, Isik NS. 2010. Effect of Particle Optical Properties on Size Distribution of Soils Obtained by Laser Diffraction. Environmental and Engineering Geoscience 16: 163-173.

Pécsi M. 1990. Loess is not just the accumulation of dust. Quaternary International 7-8: 1-21.

Prescott JR, Hutton JT. 1994. Cosmic ray contributions to dose rates for luminescence and ESR dating: Large depths and long-term time variations. Radiation Measurements 23: 497-500.

Preusser F, Andersen BG, Denton GH et al. 2005. Luminescence chronology of late Pleistocene glacial deposits in North Westland, New Zealand. Quaternary Science Reviews 24: 2207-2227.

Prud'homme C, Antoine P, Moine O et al. 2015. Earthworm calcite granules: a new tracker of millennial-timescale environmental changes in Last Glacial loess deposits. Journal of Quaternary Science 30: 529-536.

Prud'homme C, Lécuyer C, Antoine P et al. 2016. Palaeotemperature reconstruction during the Last Glacial from $\delta 180$ of earthworm calcite granules from Nussloch loess sequence, Germany. Earth and Planetary Science Letters 442: 13-20.

Pye K. 1995. The nature, origin and accumulation of loess. Quaternary Science Reviews 14: 653-667.

Pye K. 2015. Aeolian dust and dust deposits. Elsevier.

Pye K, Blott SJ. 2004. Particle size analysis of sediments, soils and related particulate materials for forensic purposes using laser granulometry. Forensic Science International 144: 19-27.

Rohdenburg H, Meyer B. 1979. Zur Feinstratigraphie und Paläopedologie des Jungpleistozäns nach Untersuchungen an südniedersächsischen und nordhessischen Lossprofilen. (Fine stratigraphy and palaeopedology of the younger Pleistocene in accordance to investigations of loess. profiles of Lowex Saxonia and North Hesse). Landschaftsgenese Landschaftsokologie Braunschw. 1-89.

Rousseau DD, Antoine P, Hatté C et al. 2002. Abrupt millennial climatic changes from Nussloch (Germany) Upper Weichselian eolian records during the Last Glaciation. Quaternary Science Reviews 21: 1577-1582.

Rousseau D-D, Sima A, Antoine P et al. 2007. Link between European and North Atlantic abrupt climate changes over the last glaciation. Geophysical Research Letters 34: L22713.

Rousseau D-D, Ghil M, Kukla G et al. 2013. Major dust events in Europe during marine isotope stage $5(130-74 \mathrm{ka})$ : a climatic interpretation of the "markers. Climate of the Past 9: 2213-2230.

Sauer D, Kadereit A, Kühn P et al. 2016. The loess-palaeosol sequence of Datthausen, SW Germany: Characteristics, chronology, and implications for the use of the Lohne Soil as a marker soil. CATENA 146: 10-29.

Schaetzl R, Thompson M. 2015. Soils: Geomorphology and Genesis. Cambridge University Press: New York.

Schaetzl RJ, Bettis EA, Crouvi O et al. 2018. Approaches and challenges to the study of loess-Introduction to the LoessFest Special Issue. Quaternary Research 89: 563-618.

Schaller K. 2000. Praktikum zur Bodenkunde und Pflanzenernährung. Geisenheim: Geisenheimer Berichte.

Schatz A-K, Scholten T, Kühn P. 2015. Paleoclimate and weathering of the Tokaj (Hungary) loess-paleosol sequence. Palaeogeography, Palaeoclimatology, Palaeoecology 426: 170-182.

Schirmer W. 2000. Eine Klimakurve des Oberpleistozäns aus dem rheinischen Löss. E\&G Quaternary Science Journal 50: 25-49.

Schönhals E, Rohdenburg H, Semmel A. 1964. Ergebnisse neuerer Untersuchungen zur Würmlöß-Gliederung in Hessen. E\&G Quaternary Science Journal 15: 199-206.

Schulte P, Lehmkuhl F. 2018. The difference of two laser diffraction patterns as an indicator for post-depositional grain size reduction in loess-paleosol sequences. Palaeogeography, Palaeoclimatology, Palaeoecology 509: 126-136.

Schulze DG, Nagel JL, Scoyoc GEV et al. 1993. Significance of Organic Matter in Determining Soil Colors In Soil Color. John Wiley \& Sons, Ltd; 71-90.

Schulte P, Lehmkuhl F, Steininger F et al. 2016. Influence of $\mathrm{HCl}$ pretreatment and organo-mineral complexes on laser diffraction measurement of loess-paleosol-sequences. CATENA 137: 392-405.

Schwertmann U. 1993. Relations Between Iron Oxides, Soil Color, and Soil Formation In Soil Color. John Wiley \& Sons, Ltd; 51-69. 
Semmel A. 1989. The importance of loess in the interpretation of geomorphological processes and for dating in the Federal Republic of Germany. Cantena Suppl 15: 179-188.

Spielvogel S, Knicker H, Kögel-Knabner I. 2004. Soil organic matter composition and soil lightness. Journal of Plant Nutrition and Soil Science 167: 545-555.

Sprafke T. 2016. Löss in Niederösterreich - Archiv quartärer Klima- und Landschaftsveränderungen. Würzburg University Press: Würzburg.

Sprafke T, Thiel C, Terhorst B. 2014. From micromorphology to palaeoenvironment: The MIS 10 to MIS 5 record in Paudorf (Lower Austria). CATENA 117: 60-72.

Strattner M, Rolf C. 1995. Magnetostratigraphische Untersuchungen an pleistozänen Deckschicht-Profilen im bayerischen Alpenvorland. Geologica Bavarica 99: 101.

Techmer A, Rolf C, Weidenfeller M. 2006. The Alsheim loess profile: Luminescence, chronology and paleomagnetic analysis. Mainzer Geowissenschaftliche Mitteilungen 113-134.

Terhorst B, Appel E, Werner A. 2001. Palaeopedology and magnetic susceptibility of a loess-palaeosol sequence in southwest Germany. Quaternary International 76-77: 231-240.

Terhorst B, Frechen M, Reitner J. 2002. Chronostratigraphische Ergebnisse aus Lößprofilen der Inn-und Traun-Hochterrassen in Oberösterreich. Zeitschrift für Geomorphologie Suppl. 127: 213-232.

Terhorst B, Sedov S, Sprafke T et al. 2015. Austrian MIS 3/2 loess-palaeosol records-Key sites along a west-east transect. Palaeogeography, Palaeoclimatology, Palaeoecology 418: 43-56.

Thiel C, Buylaert P, Murray A et al. 2011. Luminescence dating of the Stratzing loess profile (Austria) - Testing the potential of an elevated temperature post-IR IRSL protocol. Quaternary International 234: 23-31.

Thomsen KJ, Murray AS, Jain M et al. 2008. Laboratory fading rates of various luminescence signals from feldspar-rich sediment extracts. Radiation Measurements 43: 1474-1486.

Újvári G, Kok JF, Varga G et al. 2016. The physics of wind-blown loess: Implications for grain size proxy interpretations in Quaternary paleoclimate studies. Earth-Science Reviews 154: 247-278.

Uthmeier T. 2003. Micoquien, Aurignacien und Gravettien in Bayern: eine regionale Studie zum Übergang vom Mittel- zum Jungpaläolithikum.
Van Vliet-Lanoë BV. 1989. Dynamics and extent of the Weichselian permafrost in western Europe (Substage 5E to stage 1). Quaternary International 3-4: 109-113.

Van Vliet-Lanoë B. 1998. Frost and soils: implications for paleosols, paleoclimates and stratigraphy. CATENA 34: 157-183.

Vandenberghe J. 1985. Paleoenvironment and stratigraphy during the last glacial in the Belgian-Dutch border region. Quaternary Research 24: 23-38.

Vandenberghe J, Nugteren G. 2001. Rapid climatic changes recorded in loess successions. Global and Planetary Change 28: 1-9.

Vandenberghe J, Zhisheng A, Nugteren G et al. 1997. New absolute time scale for the Quaternary climate in the Chinese Loess region by grain-size analysis. Geology 25: 35-38.

Vlaminck S, Kehl M, Lauer T et al. 2016. Loess-soil sequence at Toshan (Northern Iran): Insights into late Pleistocene climate change. Quaternary International 399: 122-135.

Wallinga J, Murray A, Wintle A. 2000. The single-aliquot regenerativedose (SAR) protocol applied to coarse-grain feldspar. Radiation Measures 32: 529-533.

Wright JS. 2001. "Desert" loess versus "glacial" loess: quartz silt formation, source areas and sediment pathways in the formation of loess deposits. Geomorphology 36: 231-256.

Zander AM. 2000. Vergleich verschiedener Lumineszenzmethoden zur Datierung von Löss. Kölner Forum für Geologie und Paläontologie. Geologisches Inst. d. Univ.

Zech W, Schad P, Hintermaier-Erhard G. 2014. Böden der Welt: Ein Bildatlas, 2nd ed. Springer Spektrum.

Zeeden C, Kels H, Hambach U et al. 2016. Three climatic cycles recorded in a loess-palaeosol sequence at Semlac (Romania) Implications for dust accumulation in south-eastern Europe. Quaternary Science Reviews 154: 130-142.

Zeeden C, Krauß L, Kels H et al. 2017. Digital image analysis of outcropping sediments: Comparison to photospectrometric data from Quaternary loess deposits at Şanovița (Romania) and Achenheim (France). Quaternary International 429: 100-107.

Zens J, Zeeden C, Römer W et al. 2017. The Eltville Tephra (Western Europe) age revised: Integrating stratigraphic and dating information from different Last Glacial loess localities. Palaeogeography, Palaeoclimatology, Palaeoecology 466: 240-251. 